\title{
GANTI RUGI KEPEMILIKAN HAK ATAS TANAH MASYARAKAT KABUPATEN SIDOARJO AKIBAT PENCEMARAN LINGKUNGAN OLEH PT. LAPINDO BRANTAS
}

\author{
Nini Warsini ${ }^{1}$
}

\section{Abstrak}

This article publishes a tight research regarding the current issue on mud eruption that has happened in oil drilling area in Sidoarjo District, east java. The company that did business has influenced environment destruction and people suffered. The research itself is conducted by normative (library) legal research to propose about three problems. The author concerns are about its compensation payment on defected lands and how that payment be executed also embarks regarding responsibility of government. This research becomes one of many legal researches done to offering more figure legal enlightening through the case known as enormous environment disaster after prior tsunami was happened in Indonesia. Analyze gives focus on land law perspective about land loss and its just compensation.

Kata kunci: hukum pertanahan, ganti kerugian, pencemaran, lapindo, Sidoarjo

\section{Pendahuluan}

Dalam Hukum Tanah Nasional di Indonesia, terdapat empat macam hak atas tanah yang diatur secara tertulis, yaitu Hak Milik, Hak Guna Usaha, Hak Guna Bangunan, dan Hak Pakai. Diadakannya empat macam hak atas tanah tersebut dalam Hukum Tanah Nasional di Indonesia adalah atas pertimbangan, bahwa hak atas tanah apapun semuanya memberi kewenangan untuk memakai suatu bidang tanah tertentu dalam rangka memenuhi suatu kebutuhan tertentu.

Pada hakikatnya pemakaian tanah itu hanya terbatas untuk dua tujuan, pertama untuk diusahakan. kedua, tanah dipakai sebagai tempat untuk membangun sesuatu di atasnya. Karena semua hak atas tanah itu hak untuk memakai tanah, maka semuanya dapat dicakup dalam pengertian dan dengan nama sebutan Hak Pakai. Tetapi mengingat bahwa dalam masyarakat modern

\footnotetext{
' Penulis adalah Staf Peneliti dan Pengembangan Mahkamah Agung RI.
} 
peruntukan tanah itu bemacam-macam, maka untuk memudahkan pengenalannya, Hak Pakai tersebut masing-masing diberi empat nama yang berbeda, yaitu Hak Milik, Hak Guna Usaha, Hak Guna Bangunan, dan Hak Pakai.

Diantara Hak Pakai tersebut ada yang sifatnya sangat khusus, yang bukan hanya sekedar memberikan kewenangan untuk memakai suatu bidang tanah tertentu yang dihakki, tetapi juga mengandung hubungan psikologisemosional antara pemegang haknya dengan tanah yang bersangkutan. Hubungannya bukan sekedar hubungan tugas yang memberi kewenangan memakai suatu bidang tanah tertentu. Pemegang haknya sebagai orang Indonesia yang belum mendapat pengaruh pemikiran Barat, merasa memiliki tanah yang bersangkutan. Dirasakannya tanah tersebut sebagai kepunyaannya.

Hak pakai ini dalam Undang-Undang No. 5 Tahun 1960 Tentang Pokok Agraria (UUPA) diberi nama sebutan Hak Milik. Hak ini tidak terbatas jangka waktu berlakunya dan diperuntukkan khusus bagi warganegara Indonesia, baik untuk tanah yang diusahakan maupun untuk keperluan membangun sesuatu di atasnya. Hak Milik ini bukanlah nama asli Indonesia, tetapi sifat-sifat hak menguasai tanah yang diberi sebutan Hak Milik itu sudah terlebih dahulu dikenal dalam Hukum Adat, sebagai perkembangan dari penguasaan dan pengusahaan atau penggunaan sebagian tanah ulayat secara intensif dan terus-menerus oleh perorangan warga masyarakat Hukum Adat pemegang Hak Ulayat (Hak bersama atas tanah dalam Hukum Adat).

Persoalan hukum terutama yang berkaitan dengan masalah pengambilan tanah (biasa juga disebut dengan pembebasan tanah/pengadaan tanah) milik penduduk atau masyarakat untuk kepentingan pembangunan merupakan persoalan yang kontroversial, sebab menyangkut masalah pertanahan. di satu pihak, sejalan dengan kebijakan Pemerintah untuk melaksanakan desentralisasi dan otonomi penuh khususnya di bidang pertanahan pada awal Januari 2001 telah timbul berbagai perbedaan pemahaman dan pelaksanaan dalam bidang pengelolaan pertanahan terutama di tingkat propinsi dan kabupaten/kota.

Sehingga saat ini di daerah/kota ditemui berbagai persoalan di bidang pertanahan seperti permasalahan kelembagaan pertanahan, sumberdaya manusia, keuangan, dan mencuatnya berbagai konflik tanah yang terjadi dimasa lalu yang harus segera diselesaikan. Sebab tuntutan pembangunan akan tanah sudah sedemikian mendesak, sedangkan pada lain pihak 
persediaan tanah sudah mulai terasa sulit. ${ }^{2}$

Secara umum ciri perkotaan adalah ruang yang relatif sempit, masyarakatnya heterogen dan dinamika kegiatannya tinggi. Di beberapa bagian perkotaan menunjukan intensitas yang begitu besar sehingga menimbulkan masalah perkotaan seperti perumahan kumuh, kurangnya sanitasi, kemacetan lalu lintas dan lainnya. Kondisi ini akhirnya akan mendorong semakin kompleknya masalah pertanahan yang berkaitan dengan kepentingan perorangan, badan hukum dan negara.

Dalam Pasal 13 UU No. 24 tahun 1992 diatur mengenai proses dan dari rencana tata ruang tersebut, baik nasional, propinsi, kabupaten/kota secara terarah dan terpadu dengan langkah-langkah kegiatan sebagai berikut: (a) Menentukan arah pengembangan yang akan dicapai dilihat dari segi ekonomi, sosial, budaya, daya dukung dan daya tampung lingkungan serta fiingsi pertahanan keamanan; (b) Mengidentifikasi berbagai potensi dan masalah pembangunan dalam suatu wilayah perencanaan; (c) Perumusan perencanaan tata ruang; dan (d) Penetapan rencana tata ruang. ${ }^{3}$

Cara yang saat ini dilakukan adalah mengambil jalan pintas sebagai upaya yang lebih baik ketimbang menempuh tata cara yang menyulitkan sebagaimana yang tercantum dalam peraturan hukum tersebut. Namun, bagi warga yang terpenting adalah perlakuan yang diterima oleh aparat pemerintah terhadap tanahnya secara umum hanya akan merugikan, sebab warga memiliki ukuran yang di dalamnya terkait dengan berbagai kepentingan mengenai nilai dari tanah tersebut, sehingga ada nilai yang bersifat faktual dan ideal.

Ironisnya, warga masih dituntut untuk berkorban memberikan pengorbanan berupa kerelaan menurunkan permintaannya dari nilai faktual yang ada. Nilai faktual saja bagi warga sudah tidak cukup apalagi jika nilainya dibawah nilai faktual tersebut. Warga ingin agar nilai faktual ditetapkan secara ideal dan adil, dimana penentuannya sesuai dengan selera warga yang kadang-kadang sangat jauh di atas nilai faktual.

Sebab alasan bagi warga adalah bukan hanya tanah semata, akan tetapi menyangkut segala macam aspek yang terkait dengan tanah tersebut termasuk berbagai nilai lebih yang memang sulit dinilai dengan uang. Hal ini bagi Pemerintah merupakan sesuatu yang "keterlaluan" dan tidak mungkin untuk dipenuhi. ${ }^{4}$

\footnotetext{
${ }^{2}$ Mulyadi, "Pengadaan Tanah untuk Kegiatan Pembangunan di Perkotaan", (Jakarta: Pusat Penelitian dan Pengembangan BPN, 1998).

${ }^{3}$ Hasni, "Modul Hukum Penatagunaan Tanah/Ruang", (Jakarta: Fakultas Hukum Trisakti, 2003), hal. 72-73.
} 
Menurut Zainuddin Ali, untuk dapat melakukan penganalisaan terhadap sistem ganti rugi terhadap kasus lumpur lapindo di Kabupaten Sidoarjo, perlu dilakukan penganalisaan secara sosiologi hukum. Pengkajian dengan menggunakan pendekatan sosiologi hukum menunjukkan selain pendekatan yuridis normatif dalam mengkaji masalah hukum, masih terdapat sisi yang lain yaitu hukum dalam kenyataannya di dalam kehidupan sosial kemasyarakatan.

Hukum dalam masyarakat dimaksud bukan kenyataan dari bentuk pasal-pasal dalam perundang-undangan, melainkan sebagaimana hukum itu dioperasikan oleh masyarakat dalam kehidupan sehari-harinya. Kalau mempelajari hukum dalam kenyataannya yang sedemikian itu, maka harus keluár dari batas-batas peraturan hukum dan mengamati praktek-praktek dan atau hukum sebagaimana yang dilakukan oleh orang-orang di dalam masyarakat. $^{5}$

Salah satu kasus yang terkait dengan hak milik atas tanah adalah kasus luapan lumpur panas yang dikenal dengan nama kasus Luapan Lumpur Panas PT Lapindo Brantas, yang sudah berlangsung selama hampir enam bulan lamanya dan masih berlangung hingga kini. Kasus tersebut dimulai dengan permulaan semburan yang terjadi sejak tanggal 29 Mei tahun 2006 hingga saat ini masih belum bisa dihentikan dari kebocoran pipa gas tersebut salah satu sumur yang kemudian meluas ke beberapa sumur lainnya dan pada akhirnya menyebabkan meluapnya lumpur panas di Kabupaten Sidoarjo.

Kasus ini melibatkan tiga pihak, yaitu PT. Lapindo Brantas (Lapindo) selaku pemilik konsesi atas Blok Brantas tempat sumur yang bocor berada, atas dasar Production Sharing Contract (PSC) dengan BP Migas, dan terakhir adalah PT. Medici Citra Nusantara (MCN) selaku subkontraktor yang bertanggung jawab atas pekerjaan Drilling dalam kasus ini.

Meluapnya lumpur panas tersebut telah menyebabkan keresahan di masyarakat. Hal tersebut terjadi diantaranya disebabkan karena keberadaan lumpur panas tersebut telah memusnahkan rumah-rumah penduduk yang berada di sekitar tempat kejadian. Banyak rumah-rumah penduduk di desadesa tersebut yang rumahnya terendam oleh lumpur sehingga tidak dapat ditinggali lagi. Selain itu, keberadaan lumpur tersebut juga telah menyebabkan tertutupnya akses jalan ke beberapa tempat, sehingga tidak lagi

${ }^{4}$ Abdulrahman, "Masalah Pencabutan Hak-hak atas tanah, Pembebasan Tanah dan Pengadaan Bagi Pelaksanaan Pembangunan untuk Kepentingan Umum", (Bandung, Citra Aditya Bakti, 1996), hal. 3. 2004), hal. 20.

${ }^{5}$ Zainuddin Ali, "Sosiologi Hukum", (Palu: Yayasan Masyarakat Indonesia Baru, 
hanya menyusahkan penduduk sekitar, melainkan juga menyulitkan para penguna jalan.

Akibat hal-hal yang tidak diinginkan tersebut, terutama dengan terendamnya rumah-rumah penduduk, maka kemudian timbulah masalah mengenai Hak Milik warga atas tanah. Untuk itu dalam penulisan tesis hasil penelitian ini akan mencoba untuk membahas mengenai beberapa permasalahan yang timbul terkait dengan kasus meluapnya lumpur panas tersebut, antara lain adalah mengenai hak Milik warga atas tanah mereka yang sudah terendam lumpur panas, relokasi rumah warga, dan sertifikasi atas tanah yang bersangkutan.

\section{Rumusan Masalah}

Berdasarkan latar belakang Penulisan yang telah diuraikan sebagaimana tersebut di atas, maka penulis dalam penulisan tesis ini merumuskan beberapa permasalahan sebagai berikut:

1. Bagaimana proses ganti rugi tanah dan pembebasan hak atas tanah yang terkena lumpur Lapindo di Kabupaten Sidoarojo?

2. Bagaimana pelaksanaan ganti rugi tanah dan bangunan ysng terkena lumpur lapindo serta apakah sudah sesuai ganti rugi tersebut menurut harapan (masyarakat) maupun ketentuan yang berlaku?

3. Bagaimana Penyelesaian Ganti Rugi Tanah yang tekena lumupur Lapindo Berantas dan Sejauhmana tanggung Jawab Pemerintah dalam hal Terjadinya Pencemaran Lingkungan?

\section{Metode Penelitian}

Sehubungan dengan masalah-masalah yang telah dirumuskan sebelumnya dan dikaitkan dengan teori-teori yang ada, maka metode penelitian ini menggunakan metode Yuridis Normatif, yaitu dengan mengacu pada norma-norma hukum yang terdapat dalam peraturan perundangundangan dan norna-norma hukum yang ada dalam masyarakat. ${ }^{6}$

Disamping itu penulis juga menggunakan metode penelitian kualitatif, terlebih dahulu penulis melakukan langkah-langkah sebagai berikut:

${ }^{6}$ Sri Mamudji, dkk. "Metode Penelitian dan Penulisan Hukum", (Jakarta: Badan Penerbit Fakultas Hukum Universitas Indonesia, 2005), hal. 35. 
1. Tipe Peneltian

Penelitian ini termasuk dalam tipe penelitian empiris yaitu peneltian tentang hukum di dalam pelaksanaannya penelitian dalam tesis ini sendiri apabila diakaitkan dengan tema/konsepnya adalah bersifat normative dalam proses, prinsip, dan prosedur yang digunakan. Namun demikian, pada dasarnya penelitian ini tidak sepenuhnya bersifat normative mengingat kasus-kasus yang akan dibahas pada penulisan ini terjadi pada lingkup yang sebenarnya. $^{7}$

2. Sifat Penelitian

Penelitian ini bersifat deskriftif analitis, dengan menggambarkan peraturan perundang-undangan yang berlaku dan dikaitkan dengan teori-teori hukum, dalam peraktek pelaksanaannya yang berkaitan dengan permasalahan yang akan diteliti melaluui metode ini pula akan menguraikan dan menggambarkan mengenai fakta-fakta yang secara nyata terjadi sebagai pencerminan terhadap pelaksanaan dari peraturan perundang-udangan serta asas-asas hukum yang dikaitkan dengan teori-teori hukum dan peraktek pelaksanannya mengenai masalah kekuatan hukum terhadap sertifikat hak atas tanah. ${ }^{8}$

3. Sumber Data

a) Data Primer, yaitu data yang diperoleh langsung dari sumbernya Instansi: Badan Pertanahan Nasional (BPN) Jakarta, Kantor Wilayah Badan Pertanahan Kabupaten Sidoardo.

b) Data Skunder, yaitu data yang diperoleh dari dokumendokumen resmi, buku-buku yang berhubungan dengan masalah yang dibahas dalam tesis ini, hasil penelitian yang berwujud laporan, peraturan perundang-undangan yang terbagi menjadi:

1. Bahan hukum primer, yaitu bahan hukum yang mengikat seperti: Amåndemen Undang-Undang Dasar Negara Republik Indonesia Tahun 1945, Undang-Undang No. 5 Tahun 1960 tentang UUPA.

2. Bahan hukum skunder, yaitu yang memberikan penjelasan mengenai bahan hukum primer seperti

${ }^{7}$ Abdullah Sulaiman. "Metode Penelitian Hukum", (Jakarta: Magister (S2) Ilmu Hukum Universitas Islam Jakarta, 2004), hal. 2.

${ }^{8}$ Ibid., hal. 3 . 
literatur-literatur kepustakaan, majalah-majalah, koran/berita harian, jurnal hukum baik yang terakreditasi nasional maupun Internasional, makalah-makalah hasil seminar dan sebagainya yang berhubungan dengan permasalahan yang akan dibahas dalam penulisan tesis ini.

3. Bahan hukum tertier, yaitu bahan hukum yang memberikan petunjuk terhadap bahan hukum primer dan skunder seperti: kamus-kamus, kamus hukum, dan sejenisnya yang berhubungan dengan masalah yang akan dibahas.

4. Metode Pengumpulan Data

Dalam penulisan/penelitian tesis ini dilakukan dalam dua tahap:

a) Metode Penelitian Kepustakaan (Library Research)

Dalam metode penelitian kepustakaan ini dilakukan adalah dengan mempelajari dan membaca buku-buku, majalahmajalah, media cetak lainnya dan peraturan perundangundangan yang terkait serta bahan-bahan bacaan lainnya yang berhubungan dengan penelitian tesis ini, dalam rangka untuk mendapatkan landasan teoritis sebagai dasar dalam melakukan penelitian penulisan tesis ini.

b) Metode Penelitian Lapangan (Field Research)

Metode penelitian ini yaitu penelitian dilakukan dengan mengumpulkan data langsung dari pihak yang berkompeten, untuk itu dilakukan metode wawancara dengan pihak yang terkait seperti wawancara dilakukan secara langsung dan terbuka dengan responden dan melalui penyampaian pedoman wawancara, yaitu dengan mengajukan daftar pertanyaan secara tertulis kepada responden yang ditentukan. Data diolah dan dianalisis dengan menggunakan pendekatan kualitatif

Penelitian kualitatif dalam pengumpulan data dapat digolongkan ke dalam dua cara yaitu metode interaktif dan metode non interaktif atau dokumentatif, sehingga dalam penelitian ini sangat besar kemungkinan menggunakan lebih dari satu atau banyak strategi penelitian untuk mendapatkan data yang memadai.

Wawancara dilakukan secara terbuka bersifat informal dan formal dengan maksud untuk menggali data dan informasi tentang kekuatan hukum terhadap sertifikat tanah, Wawancara dilakukan pada waktu yang dianggap tepat agar 
mendapatkan data yang mendalam dari hal yang dapat di amati langsung, tanpa mengabaikan persiapan wawancara seperti itu ada kesepakatan sebelumnya dengan responden atau pertanyaan spontan di lapangan bila ada hal baru menurut pengamatan (observasi) yang tidak tertulis dalam daftar pertanyaan. Sebagai data sekunder dikumpulkan dari berbagai literature yang diperlukan, dan data ini digunakan untuk melengkapi data yang diperoleh melalui wawancara dan obsevasi. ${ }^{9}$

\section{Metode Analisis Data}

Sebagai upaya untuk dapat menjawab atau memecahkan permasalahan yang diangkat dalam penulisan Tesis ini, dilakukan suatu analisis yang termasuk dalam analisis deskriftif kualitatif. Dimana setelah pengumpulan data dilakukan kemudian dianalisis, sehingga dapat ditarik suatu kesimpulan yang dapat dipertanggung jawabkan secara ilmiah.

Proses pengumpulan dan analisa data penelitian kualitatif dalam prakteknya tidak secara mudah dipisahkan. Kedua kegiatan itu kadang berjalan bersamaan, artinya menganalisa data seharusnya dikerjakan bersama-sama dengan selesainya pengumpulan data. Analisa data dilakukan melalui langkah-langkah berupa; ${ }^{10}$

a) Analisis selama pengumpulan data dan analisa data penelitian meliputi; (1) mengambil keputusan mengenai jenis kajian yang akan diperoleh dan membatasi lingkup kajian, (2) mengembangkan pertanyaan-pertanyaan, (3) merencakan tahapan pengumpulan data dengan memperhatikan hasil pengamatan sebelumnya.

b) Analisis sesudah pengumpulan data dan-mengembangkan mekanisme terhadap data yang dikatagorikan itu.

${ }^{9}$ Abdullah Sulaiman., Ibid, hal. 4.

${ }^{10} \mathrm{Ibid}$. 


\section{Pembahasan}

\section{A. Penyelesaian Ganti Rugi Tanah dan Bangunan di Kabupaten Sidoarjo}

Ganti rugi menurut Perpres No. 65 tahun 2006 Tentang Perubahan Atas Peraturan Presiden Tentang Pengadaan Tanah Bagi Pelaksanaan Pembangunan Untuk Kepentingan Umum, didefinisikan sebagai bentuk pembayaran atas tanah milik warga yang dikorbankan guna pengadaan tanah untuk pembangunan fasiltitas kepentingan umum ${ }^{11}$.

Mengenai besarnya ganti rugi langsung ditetapkan oleh Panitia Pengadaan tanah, dan tidak terdapat pengusulan terlebih dahulu ${ }^{12}$. Jangka waktu mengenai ganti rugi ini melalui musyawarah adalah 120 hari ${ }^{13}$. Ganti rugi berupa uang saja Perpres No. 65 tahun 2006 hanya berupa uang saja ${ }^{14}$.

Dalam kasus ini, warga menuntut ganti rugi sebagai pertanggungjawaban kepada PT. Lapindo Brantas dari segi Hukum Perdata. Dasar dari tuntutan ganti rugi tersebut dapat dilihat dalam pasal 1365 KUHPerdata mengenai Perbuatan Melawan Hukum (PMH) yang menyatakan bahwa: "Tiap perbuatan melanggar hukum, yang membawa kerugian kepada orang lain, mewajibkan orang yang karena salahnya menerbitkan kerugian itu, mengganti kerugian tersebut".

Selain Pasal tersebut, pasal lain yang juga dapat diterapkan adalah Pasal 1366 KUHPerdata yang menyatakan: "Setiap orang bertanggung jawab tidak saja untuk kerugian yang disebabkan perbuatannya, tetapi juga untuk kerugian yang disebabkan kelalaian atau kurang hatihatinya". Ketentuan ini dapat diterapkan jika terbukti kebocoran sumur terjadi karena pihak yangg bersangkutan kurang hati-hati atau lalai. Ketentuan lainnya yang dapat dilihat adalah Pasal 34 (1) UU No. 23 Tahun 1997 Tentang Lingkungan Hidup yang menyatakan:

"Indonesia (A), Peraturan Presiden No. 65 Tahun 2006 Tentang Perubahan Atas Peraturan Presiden Tentang Pengadaan Tanah Bagi Pelaksanaan Pembangunan Untuk Kepentingan Umum, Pasal. 5.

\footnotetext{
${ }^{12}$ Indonesia (A), Ibid.. Pasal. 7

${ }^{13}$ Indonesia (A), Ibid.. Pasal. 10 ayat 1

${ }^{14}$ Indonesia (A), Ibid.. Pasal. 13 huruf a.
} 
"Setiap perbuatan melanggar hukum berupa pencemaran dan/atau perusakan lingkungan hidup yang menimbulkan kerugian pada orang lain atau lingkungan hidup, mewajibkan penanggung jawab usaha dan/atau kegiatan untuk membayar ganti rugi dan/atau melakukan tindakan tertentu".

Pasal ini mengatur mengenai pertanggungjawaban secara perdata, sesuai dengan ketentuan dalam pasal 1365 KUHPerdata tentang Perbuatan Melawan Hukum. Berdasarkan ketentuan dalam pasal ini, selain diharuskan membayar ganti rugi, pencemar dan/atau perusak lingkungan hidup dapat pula dibebani oleh hakim untuk melakukan tindakan hukum tertentu, misalnya perintah untuk:

1. Memasang atau memperbaiki unit pengelolaan limbah sehingga limbah sesuai dengan baku mutu lingkungan hidup yang ditentukan;

2. Memulihkan fungsi lingkungan hidup;

3. Menghilangkan atau memusnahkan penyebab timbulnya pencemaran dan/atau perusakan lingkungan hidup.

Terkait bentuk pertanggungjawaban, terdapat kerancuan dalam bentuk pertanggung\&jawaban yang akan dilakukan oleh PT. Lapindo Brantas. Berdasarkan penelitian yang dilakukan, bentuk pertanggungjawaban yang akan dilakukan adalah memberi ganti rugi dalam tiga bentuk yaitu, membeli area yang terkena dampak lumpur langsung, merehabilitasi, dan menyewa tanah untuk dijadikan kolam penampungan lumpur (pond).

Mengenai keinginan warga yang meminta tanahnya untuk dibeli, tidak bisa dilakukan dalam waktu dekat. Alasan yang dikemukakan oleh PT. Lapindo Brantas, berdasarkan hasil penelitian, adalah karena prosesnya nanti harus melibatkan Lapindo, Satlak, dan Pemda Sidoarjo dan kalaupun jadi dibeli itu membutuhkan data yang valid mengenai ukuran dan luas tanah, karena jika ada kesalahan sedikit saja itu bisa menimbulkan konflik dan sekarang ini sedang dilakukan pendataannya.

Selain itu, Lapindo adalah perusahaan minyak atau oil and gas yang bekerjasama langsung dengan pemerintah yang mengharuskan semua barang-barang yang dibeli atau dimiliki Lapindo seperti gedung, lahan dan peralatan semua menjadi aset negara. Tetapi dengan berjalannya waktu kemungkinan akan ada wacana kearah pembelian tanah.Namun, bentuk ganti rugi berupa pembelian tanah warga bertentangan dengan Hukum Tanah Nasional. Hal tersebut dikarenakan: 
1. Berdasarkan Pasal 21 ayat 1 jo ayat 4 UUP A, PT. Lapindo Brantas bukanlah subyek Hak Milik atas tanah dikarenakan PT. Lapindo Brantas adalah badan hukum perdata;

2. Ketentuan mengenai jual beli tanah diatur berdasarkan Hukum Perdata (Hukum Perjanjian Barat), dan karenanya berlakulah ketentuan dalam Kitab UU Hukum Perdata (KUHPerdata). Dalam pasal,1381 KUHPerdata dinyatakan bahwa salah satu penyebab hapusnya perikatan adalah karena musnahnya barang yang terutang atau dengan kata lain musnahnya objek dalam suatu perjanjian; Dalam kasus perjanjian jual beli sebagai suatu bentuk ganti rugi yang terjadi antara PT. Lapindo dengan pihak warga Kabupaten Sidoarjo, maka perjanjian tersebut dapatlah hapus dikarenakan tanah sebagai objek perjanjian sudah musnah.

3. Selain itu juga warga bukanlah pemilik hak atas tanah lagi, karena hak miliknya telah hapus disebabkan tanahnya telah musnah. Sedangkan jual beli tanah disini adalah penyerahan hak atas tanah yang dijual kepada pembeli yang pada saat yang sama membayar penuh kepada penjual harga yang telah disetujui bersama, ${ }^{15}$ dan karena hak atas tanah yang bersangkutan sudah tidak ada lagi, maka perjanjian tersebut adalah menjadi hapus.

Hingga saat ini alternatif yang paling baik untuk pengungsi adalah relokasi sementara atau sewa tempat tinggal, karena untuk membicarakan pembelian tanah itu membutuhkan waktu yang lama. Maka dari itu diharapkan agar warga bisa memahami kebutuhan yang mendesak sekarang ini dan bersedia untuk direlokasikan.

Relokasi itu sendiri dapat dilakukan dengan bantuan pemerintah dan Lapindo atau warga pengungsi bisa mencari tempat sendiri untuk jangka waktu dua tahun kedepan. atau jika tempat tinggal dan prasarana tersebut disediakan oleh Lapindo, maka warga bisa memperoleh kesempatan untuk memilikinya.

Sebelumnya Menteri Tenaga Kerja dan Transmigarasi, Erman Suparno, melontarkan wacana untuk melakukan program transmigrasi sebagai penyelesaian dari masalah sosial musibah luapan lumpur Lapindo. Adapun daerah sasaran relokasi warga korban luapan lumpur adalah Riau, Kalimantan Tengah, dan Maluku Utara, namun warga menolak, dengan alasan ekonomi mereka tidak layak untuk ditransmigrasikan, sebagian besar termasuk dalam ekonomi yang berkecukupan. Selain itu juga terdapat tuntutan warga agar tempat

${ }^{15}$ Boedi Harsono, Op. Cit., hal. 29. 
relokasi nanti sama dengan tempat tinggal mereka selama ini. Sebagai pengganti transmigrasi, solusi yang paling dirasa tepat adalah relokasi permanen di wilayah lain di Sidoarjo.

Sebagai solusi yang tepat hingga saat ini adalah relokasi permanen di wilayah lain di Sidoarjo. Hal tersebut hanya dapat dilakukan dengan cara transmigrasi. Warga yang yang tanahnya terkena dampak lumpur panas ditempatkan di daerah Transmigrasi yang sebelumnya telah ditetapkan oleh Pemerintah sebagai daerah transmigrasi dengan Keputusan Presiden. ${ }^{16}$

Daerah transmigrasi yang dimaksud adalah daerah yang masih kosong atau kurang padat penduduknya, areal tanah yang masih cukup luas bagi kemungkinan usaha-usaha pertanian dalam arti luar dan memungkinkan untuk memberikan lapangan pekerjaan dan lapangan penghidupan baru yang lebih baik serta memiliki arti vital dari segi keamanan bagi negara dan bangsa selain itu apabila terdapat alasanalasan lain yang dipandang perlu oleh Pemerintah. ${ }^{17}$

Pertimbangan-pertimbangan bagi warga yang terkena dampak lumpur panas untuk dapat melakukan transmigrasi adalah adanya bencana alam dan jenis kesuburan tanah yang tidak menguntungkan.

Adapun pertimbangan-pertimbangan sosial, ekonomi dan pertahanan-keamanan berdasarkan Pasal 10 Undang-undang No. 3 Tahun 1972 tentang Ketentuan-ketentuan Pokok Transmigrasi yang dapat dijadikan alasan bagi pemerintah untuk melaksanakan transmigrasi bagi warga Sidoarjo, yaitu:

1. Kepadatan penduduk dan lapangan pekerjaan yang sangat sempit;.

2. Luas areal tanah pertanian yang sangat terbatas;

3. Jenis kesuburan tanah yang tidak menguntungkan;

4. Adanya bencana alam;

5. Gangguan keamanan.

Selain itu, keinginan dari warga Sidoarjo bukanlah termasuk dalam kategori kepentingan umum, seperti yang dinyatakan Pasal 5 Perpres. No 65 Tahun 2006 Tentang Perubahan Atas Peraturan Presiden Tentang Pengadaan Tanah Bagi Pelaksanaan Pembangunan Untuk Kepentingan Umum.

16 Indonesia (B), Undang-undang No. 3 tahun 1972 tentang Ketentuan-ketentuan Pokok Transmigrasi. Pasal 11 ayat 1 dan 2.

${ }^{17}$ Indonesia (C), Undang-undang Tentang Pokok-Pokok Agaria (UUPA), Penjelasan Pasal 11 ayat 1 dan 2 . 
Dalam kasus ini, transmigrasi nampaklah merupakan jalan yang terbaik bagi warga yang terkena dampak lumpur panas, sangatlah mustahil untuk memenuhi keinginan warga mendapatkan tanah relokasi di sekitar Sidoarjo karena sudah tidak terdapat lagi tanah yang layak dan ideal sebagai daerah relokasi.

Hal ini merujuk dari Pasal 11 Undang-Undang No. 3 Tahun 1972 tentang Ketentuan-ketentuan Pokok Transmigrasi dikaitkan dengan kriteria tanah yang layak bagi daerah relokasi.

Apabila warga Kabupaten Sidoajo berhasil direlokasikan, maka mereka tetap dapat mengajukan permohonan hak milik atas tanah dan dapat mengajukan permohonan sertifikat hak milik atas tanah. Mengenai cara memperoleh sertifikat hak milik atas tanah, ada dua cara yang bisa ditempuh dalam memperoleh sertifikat hak milik atas tanah untuk pertama kali, artinya sebelum tanah-tanah tersebut belum pernah disertifikatkan.

Cara pertama adalah menggunakan cara pendaftaran tanah Sporadik. inisiatif datang dari pihak pemohon sertifikat, dimana pemohon sertifikat harus mendatangi Kantor Pertanahan, pemohon sertifikat akan diminta mengisi dan menandatangani formulir khusus permohonan sertifikat seraya menyerahkan berkas persyaratan atau kelengkapan seperlunya (termasuk surat kuasa dari pemilik kepada orang yang diberi kuasa apabila penerima mengurus tanah pemilik) dan membayar sejumlah biaya yang telah ada daftar tarifhya. Jadi, cara demikian inisiatif datang dari pemilik tanah.

Cara pertama ini bisa juga dilakukan secara massal, yaitu beberapa pemilik (atas kuasanya) yang tanahnya saling berdekatan secara bersamaan mengajukan permohonan pensertifikatan ke loket khusus pada Kantor Pertanahan. permohonan tersebut dapat dilakukan kapan saja atau bukan hari libur kantoran.

Cara kedua adalah menggunakan cara pendaftaran tanah Sistematik. Inisiatif datang dari kantor pertanahan, dimana pemohon didatangi langsung oleh orang-orang Kantor Pertanahan dan beberapa orang aparat desa/kelurahan yang tergabung dalam Panitia Ajudikasi. Panitia ini memang ditugaskan oleh Kepala BPN untuk mensertifikasikan tanah-tanah penduduk dalam satu wilayah desa/kelurahan. biaya pendaftaran tanah seperti ini dibebankan kepada APBN (Anggaran Pendapatan dan Belanja Negara) dan uang pinjaman negara dari Bank Dunia. Jadi, pada cara ini inisiatif datang dari pemerintah/BPN. 
Sedangkan untuk memperoleh sesuatu hak atas tanah serta mendapatkan sertifikat hak atas tanah sebagai tanda bukti kepemilikan dapat ditempuh melalui dua cara, yaitu:

1. Konversi bekas hak lama dan tanah bekas hak milik adat;

2. Permohonan hak atas Tanah Negara.

Karena dalam kasus terendamnya tanah warga Kabupaten Sidoarjo akibat luapan lumpur panas PT. Lapindo Brantas ini tanah yang terendam secara otomatis menjadi tanah negara, maka yang akan dibahas dalam penulisan ini adalah mengenai permohonan hak atas tanah negara sebagai salah satu cara untuk memperoleh sesuatu hak atas tanah serta mendapatkan sertifikat hak atas tanah sebagai tanda bukti kepemilikan.Tanah negara dapat dibedakan menjadi dua jenis yaitu:

1. Tanah Negara Bebas

Tanah Negara Bebas adalah tanah negara yang langsung dibawah penguasaan negara, dimana di atas tanah tersebut tidak ada satupun hak yang dipunyai oleh pihak lain selain negara.

Mengenai tanah negara bebas ini bisa langsung diajukan permohonan hak kepada negara/pemerintah dengan melalui suatu prosedur yang lebih pendek daripada prosedur terhadap tanah negara tidak bebas. Tata cara Permohonan Hak Milik atas Tanah negara Bebas dapat dilakukan apabila tanah negara bebas tersebut berada dalam lokasi pelaksanaan pendaftaran tanah sistematik atau proyek Nasional Agraria yang misalnya kebetulan baru akan atau sedang berlangsung di lokasi tanah yang bersangkutan ${ }^{18}$.

2. Tanah Negara Tidak Bebas

Tanah Negara Tidak Bebas adalah tanah negara yang diatasnya sudah ditumpangi oleh suatu hak punya pihak-pihak lain, misalnya:

a) Tanah Negara yang di atasnya ada Hak Pengelolaan yang dipunyai oleh Pemerintah Daerah/Kota;

b) Tanah Negara yang di atasnya ada Hak seperti Hak Guna Usaha, yang dipunyai oleh BUMN maupun Badan Usaha Swasta yang bergerak pada bidang usaha pertanian, perkebunan, peternakan, dan perikanan;

${ }^{18}$ Disarikan dari Badan Kepala Pertanahan Nasional No.9 Tahun 1999 tentang Tata Cara Pemberian dan Pembatalan Hak Atas Tanah negara dan Hak Pengelolaan, yang berlaku efektif sejak peraturan ini ditetapkan yaitu tanggal 14 Oktober 1999. 
c) Tanah Negara yang di atasnya ada Hak Pakai, yang dipunyai oleh WNI atau Badan-Badan Usaha baik Swasta Dalam Negeri (PMDN) maupun swasta asing (PMA);

d) Tanah Negara yang di atasnya ada Hak Guna Bangunan.

Terhadap tanah-tanah negara tidak bebas tersebut, maka baru bisa diajukan permohonan hak atas tanah kepada negara dan menjadi tanah hak milik apabila pemohon hak telah memperoleh izin dan/atau membebaskan hak-hak yang ada di tanah negara tersebut dari pemegangnya dengan cara membayar sejumlah uang tertentu ataupun secara gratis.

Apabila permohonan atas tanah tersebut dikabulkan negara atau pemerintah yang dibuktikan dengan diterimanya Surat keputusan Pemberian Hak Milik dari pemerintah kepada pemohon hak milik, maka barulah pemohon dapat disebut sebagai penerima hak. Yang dimaksud dengan pemerintah dalam hal ini adalah Kepala BPN atau Kepala Kanwil BPN Propinsi atau Kepala Kantor Pertanahan Kabupaten/Kota, sesuai dengan tingkat dan cakupan kewenangannya. Setelah Kantor Pertanahan mendaftarkan (membukukan dan mensertifikatkan) tanah pemberian negara tersebut, maka barulah status penerima hak berubah menjadi pemegang hak milik atas tanah tersebut.

\section{B. Pelaksanaan Ganti Rugi Tanah dan Bangunan yang Terkena Lumpur PT. Lapindo Brantas}

Dalam UU No. 24 Tahun 1992 diatur mengenai hak setiap orang dalam penataan ruang. Salah satu hak setiap orang dalam penataan ruang sebagaimana yang dimuat dalam Pasal 4 ayat (2) UU No. 24 Tahun 1992 adalah sebagai berikut: ${ }^{19}$

Setiap orang berhak memperoleh penggantian yang layak atas kondisi yang dialaminya sebagai akibat dari pelaksanaan kegiatan pembangunan yang sesuai dengan rencana tata ruang. Pengertian penggantian yang layak dirumuskan dalam Pasal 4 ayat (2) huruf c UU No.24 Tahun 1992 yaitu Nilai dari penggantian itu tidak mengurangi tingkat kesejahteraan orang yang bersangkutan.

${ }^{19}$ Indonesia (D), Undang-Undang No. 24 Tahun 1992, Pasal 4 ayat (a). 
Berdasarkan ketentuan dalam Pasal 4 ayat (2) huruf c UU No.24 Tahun 1992 yang menjadi salah satu dasar hukum bagi pembentukan Keppres No. 55 tahun 1993 dan Permeneg Agraria/Kepala BPN No.I Tahun 1994, maka seharusnya kedua peraturan tersebut tidak lagi menggunakan istilah ganti rugi akan tetapi menggunakan istilah penggantian yang layak. Dengan demikian, kedua peraturan tersebut tidak konsisten melaksanakan UU No. 24 tahun $1992 .{ }^{20}$

Oleh karena dalam Keppres No.55 tahun 1993 dan Permeneg Agraria/Kepala BPN No.I tahun 1994 terlanjur menggunakan istilah ganti rugi. Berdasarkan Pasal 12 Keppres No.5 tahun 1993 maka $^{21}$ : Ganti rugi dalam pengadaan tanah untuk kepentingan umum diberikan untuk: Hak atas tanah, bangunan, tanaman, dan benda- benda lain yang berkaitan dengan tanah seperti meteran air, listrik, antena parabola, pagar, dan Iain-lain.

Bentuk ganti rugi dalam pengadaan tanah untuk kepentingan umum menurut Pasal 13 Keppres No.55 tahun 1993 adalah uang, tanah pengganti, pemukiman kembali, gabungan dari dua atau lebih untuk gantis sebagaimana dimaksud dalam huruf a, b dan c, serta bentuk lain yang disetujui oleh pihak-pihak yang bersangkutan. Bentuk lain dari ganti rugi itu dapat berupa pemegang hak atas tanah diikutsertakan dalam program transmigrasi, atau Pemerintah memberikan fasilitas kepada pemegang hak atas tanah untuk menunaikan ibadah haji dari seluruh atau sebagian ganti rugi tersebut. ${ }^{22}$

Ketentuan mengenai dasar dan cara perhitungan ganti rugi diatur dalam Pasal 15 Keppres No.55 tahun 1993, yang ditetapkan atas dasar:

a) Harga tanah yang didasarkan atas nilai nyata atau sebenarnya dengan memperhatikan Nilai Jual Obyek Pajak (NJOP) yang terakhir untuk tanah yang bersangkutan.

b) Nilai jual Bangunan yang ditaksir oleh Instansi Pemerintah Daerah yang bertanggung jawab di bidang bangunan.

c) Nilai jual Tanaman yang ditaksir oleh instansi Pemerintah Daerah bertanggung jawab di bidang pertanian.

Dalam praktek pengadaan tanah untuk kepentingan umum, persoalan ganti kerugian terhadap bangunan, tanaman, dan benda-

\footnotetext{
${ }^{20}$ Pro Justice, Op. Cit., hal. 23.

${ }^{21}$ Keppres No.5 tahun 1993 Pasal 12.

${ }^{22}$ Ibid, hal. 24.
} 
benda lain yang berkaitan dengan tanah namun tidak banyak menimbulkan hambatan dalam menetapkan nilainya. Namun demikian, persoalan yang sering timbul adalah mengenai penetapan besarnya ganti rugi terhadap hak atas tanah. Antara pemegang hak atas tanah dengan instansi pemerintah yang memerlukan tanah sering sulit tercapai kesepakatan mengenai besarnya ganti rugi.

Berkaitan dengan harga tanah dalam pemberian kerugian, dalam pasal 16 ay at (1) Permeneg Agraria/kepala BPN No.l tahun 1994 memberikan pengaturan mengenai faktor-faktor yang mempengaruhi harga tanah, yaitu lokasi tanah, jenis hak atas tanah, status penguasaan tanah, peruntukan tanah, kesesuaian penggunaan tanah dengan rencana tata ruang wilayah, prasarana yang tersedia, fasilitas dan utilitas, lingkungan, Iain-lain yang mempengaruhi harga tanah.

Pasal 17 Permeneg Agraria/kepala BPN No.l tahun 1994 mengatur mengenai taksiran nilai tanah menurut jenis hak atas tanah dan status penguasaan tanah, yaitu:

\section{HakMilik}

a. yang sudah bersertifikat dinilai $100 \%$;

b. yang belum bersertifikat dinilai $90 \%$;

2. Hak Guna Usaha

a. yang masih berlaku dinilai $80 \%$, jika perkebunan itu masih diusahakan dengan baik;

b. yang sudah berakhir dinilai $60 \%$, jika perkebunan itu masih diusahakan dengan baik;

c. Hak Guna Usaha yang masih berlaku dan yang sudah berakhir tidak diberi ganti kerugian jika perkebunan itu tidak diusahalran dengan baik;

d. Ganti kerugian tanaman perkebunan ditaksir oleh instansi pemerintah.

3. Hak Guna Bangunan

a. yang masih berlaku dinilai $80 \%$;

b. yang sudah berakhir dinilai $60 \%$ jika tanahnya masih pakai sendiri atau oleh orang lain atas persetujuannya, dan bekas pemegang hak tanah mengajukan perpanjangan/pembaruan hak selambat-lambatnya 1 (satu) tahun haknya berakhir atau hak itu berakhir belum lewat 1 tahun.

4. Hak Pakai

a. yang jangka waktunya tidak dibatasi dan berlaku selama tanahnya dipergunakan untuk keperluan tertentu dinilai $100 \%$;

b. hak pakai dengan jangka waktu paling lama 10 tahun $70 \%$; 
c. hak pakai yang sudah berakhir dinilai $50 \%$ jika tanahnya masih dipakai sendiri atau oleh orang lain atas persetujuannya, dan bekas pemegang hak telah mengajukan perpanjangan/pembaruan hak-hak selambat-lambatnya 1 tahun setelah haknya berakhir atau hak itu belum berakhir lewat 1 tahun.

5. Tanah wakaf dinilai $100 \%$ dengan ketentuan ganti kerugian diberikan dalam bentuk tanah, bangunan, dan perlengkapan yang diperlukan.

Dasar bagi perencanaan dan pelaksanaan pembangunan untuk kepentingan umum adalah Final Design Engineering, SP 2 LP, kemudian 2 atau lebih wilayah dengan SK Gubernur satu wilayah dengan SK Walikota/Bupati, Izin Lokasi kurang dari $1 \mathrm{Ha}$ dapat dilakukan oleh instansi yang memerlukan tanah, izin penentuan lahan, dan Panitia Pembebasan Tanah (P2T).

Dalam Keppres No.55 Tahun 1993 dan Permeneg Agraria/Kepala BPN No.l tahun 1994 tidak hanya mengenai ganti rugi, tetapi juga diatur mengenai pemberian santunan ini diatur secara tegas dalam Pasal 20 Permeneg Agraria/Kepala BPN No.I Tahun 1994.

Dalam Keppres No.55 tahun 1993 ditetapkan bahwa cara perhitungan harga tanah didasarkan atas nilai nyata atau sebenarnya, dengan memperhatikan NJOP (Nilai Jual Obyek Pajak) Bumi \& Bagunan terakhir. Perkataan dengan memperhatikan di sini, menunjukkan bahwa dalam menetapkan besarnya ganti rugi atas tanah tidak mengikat didasarkan pada NJOP Bumi \& Bangunan, oleh karena asas dalam pengadaan tanah untuk kepentingan umum adalah musyawarah para pihak yang bersangkutan.

Asas musyawarah dalam pengadaan tanah untuk kepentingan umum dimuat dalam pasal 9 Keppres No.55 Tahun 1993, pengertian musyawarah itu sendiri dirumuskan dalam Pasal 1 ayat (5) nya, yaitu:

Proses atau kegiatan saling mendengar dengan sikap menerima pendapat dan keinginan yang didasarkan atas kesukarelaan antara pemegang hak atas tanah dan pihak yang memerlukan tanah, untuk memperoleh kesepakatan mengenai bentuk dan besarnya ganti rugi.

Musyawarah untuk menetapkan ganti rugi dilakukan langsung antara Instansi Pemerintah yang memerlukan tanah dengan 
pemegang hak atas tanah atau kuasanya, dipimpin oleh Ketua Panitia Pengadaan Tanah. Musyawarah yang dilakukan oleh para pihak terkait menurut Hasanudin adalah betul-betul musyawarah dan bukan pengarahan (apalagi pemaksaan), sehingga proses kegiatan saling mendengar dengan sikap saling menerima pendapat dan keinginan yang didasarkan atas kesukarelaan antara pihak-pihak yang bermusyawarah dapat dilaksanakan dengan baik.

Dalam musyawarah ini kedua belah pihak mempunyai kedudukan yang sama dalam menentukan keinginan, tidak boleh ada penekanan dan pemaksaan kehendak dari pihak yang satu kepada pihak yang lain, dan tidak berisi instruksi atau pengarahan dari instansi pemerintah yang memerlukan tanah yang harus dipatuhi oleh pemegang hak atas tanah. Dalam musyawarah ini harus menempatkan kedua belah pihak sebagai subyek dari persoalan mengenai ganti rugi.

Oleh karena asas perolehan tanah dalam pengadaan tanah untuk kepentingan umum adalah musyawarah maka besarnya kerugian atas tanah itu dapat lebih besar atau kecil dari NJOP Bumi dan Bangunan tahun terakhir maupun besarnya taksiran nilai tanah sebagaimana yang disebutkan dalam pasal 17 Permeneg Agraria/Kepala BPN No.l Tahun 1994 yang harus diperhatikan oleh instansi pemerintah yang memerlukan tanah dalam menentukan besarnya ganti rugi adalah tidak menyebabkan perubahan terhadap pola hidup pemegang hak atas tanah atau tidak boleh mengurangi tingkat kesejahteraan pemegang hak atas tanah.

Apabila dalam musyawarah telah dicapai kesepakatan pemegang hak atas tanah dengan instansi pemerintah yang memerlukan tanah, maka ketua panitia pengadaan tanah menerbitkan keputusan mengenai bentuk dan besarnya ganti rugi sesuai dengan kesepakatan tersebut. Keputusan tersebut disampaikan kepada pemegang hak atas tanah dan instansi pemerintah yang memerlukan tanah.

Musyawarah yang dilakukan antara pemegang hak atas tanah dengan instansi pemerintah yang memerlukan tanah yang dipimpin oleh ketua panitia pengadaan tanah untuk menetapkan bentuk dan besarnya ganti rugi tidak selalu mencapai kesepakatan. Apabila dalam musyawarah tersebut tidak mencapai kesepakatan sedangkan keperluan akan tanah bagi Instansi Pemerintah sangat mendesak maka oleh instansi pemerintah yang memerlukan tanah 
dilakukan konsinyasi (menitipkan uang ganti rugi ke Pengadilan Negeri setempat.

Di sini konsinyasi dikenal, tetapi untuk kepentingan penyampaian ganti rugi yang telah disepakati oleh orang yang bersangkutan tidak dapat ditemukan bukan sebagaimana yang lazim terjadi dalam praktek sekarang dimana konsinyasi dilakukan justru sebelum ada kesepakatan mengenai besar dan jumlah ganti rugi antara pemegang hak atas tanah, Panitia Pengadaan Tanah dan Instansi pemerintah yang memerlukan tanah, yang hanya ditentukan oleh sepihak saja yaitu oleh pihak instansi pemerintah yang memerlukan tanah'dengan menitipkan jumlah uang yang dihitungkan menurut tafsiran pihak instansi pemerintah sendiri di Kepaniteraan Pengadilan Negeri setempat. Sehingga dapat menimbulkan kesan adanya semacam pemaksaan dan pemilik atau pemegang hak hanya menyetujui saja. ${ }^{23}$

Upaya konsinyasi dalam pengadaan tanah ini dapat dikatakan sebagai bentuk hak atas tanah secara terselubung oleh instansi pemerintah yang memerlukan tanah. Praktek demikian ini juga dapat dikatakan telah melangkahi kewenangan Presiden karena pengambilan tanah-tanah secara sepihak untuk kepentingan umum adalah kewenangan Presiden melalui pencabutan hak atas tanah.

Dalam hal musyawarah antara pemegang hak atas tanah dengan Instansi Pemerintah yang memerlukan tanah untuk menetapkan bentuk dan besamya ganti rugi tidak tercapai kesepakatan, maka Keppres No. 55 Tahun 1993 memberikan pengaturan yaitu apabila musyawarah telah diupayakan berulangkali dan kesepakatan mengenai bentuk dan besamya ganti rugi tidak tercapai kesepakatan maka Keppres No.55 Tahun 1993 memberikan pengaturan yaitu apabila musyawarah telah diupayakan berulangkali dan kesepakatan mengenai bentuk dan besamya ganti rugi tidak tercapai juga Panitia Pengadaan Tanah mengeluarkan keputusan mengenai bentuk dan besamya ganti rugi dengan memperhatikan pendapat, keinginan, saran, dan pertimbangan yang berlangsung dalam musyawarah ${ }^{24}$. Keputusan mengenai bentuk dan besamya ganti rugi yang diterbitkan oleh Ketua Panitia

${ }^{23}$ Abdurrahman, Op. Cit., hal. 49.

${ }^{24}$ Sony Bachtiar, "Ganti Rugi Pengadaan Tanah untuk Kepentingan Umum", (Jakarta, Lucky Lestari), 1997, hal. 20. 
Pengadaan Tanah tersebut disampaikan kepada pemegang hak atas tanah dan instansi Pemerintah yang memerlukan tanah. ${ }^{25}$

Apabila hak atas tanah tidak menyetujui dan besarnya ganti rugi sebagaimana yang ditetapkan dalam keputusan Ketua Panitia Pengadaan Tanah, maka pemegang hak atas tanah dapat mengajukan keberatan kepada Gubernur Kepala Daerah Tingkat 1 disertai dengan penjelasan mengenai sebab-sebab dan alasan keberatan tersebut. ${ }^{26}$

Meskipun Keppres No. 55 Tahun 1993 maupun Permeneg Agraria No.1 Tahun 1994 memberikan kesempatan kepada para pemegang hak atas tanah untuk mengajukan keberatan atau keputusan Gubernur, namun kedua peraturan ini tidak mengatur secara tegas berapa lama waktu yang disediakan lagi pemegang hak atas tanah untuk dapat mengajukan keberatan keputusan Gubernur.

Usul penyelesaian pencabutan hak atas tanah diajukan oleh Gubernur kepada Menteri Negara Agraria/Kepala Agraria/Kepala BPN melalui Menteri Dalam Negeri, dengan tembusan kepada Menteri dari Instansi yang memerlukan tanah dan Menteri Kehakiman. Setelah menerima usul penyelesaian pencabutan hak atas tanah dari Gubernur tersebut, Menteri Negara Agraria/Kepala BPN berkonsultasi dengan Menteri Dalam Negeri, Menteri Instansi Pemerintah yang memerlukan tanah dan Menteri Kehakiman. Permintaan untuk melakukan pencabutan hak atas tanah disampaikan kepada Presiden oleh Menteri Negara Agraria/Kepala BPN yang ditandatangani oleh Menteri Dalam Negeri, Menteri dari Instansi yang memerlukan tanah dan Menteri Kehakiman. ${ }^{27}$

Cara yang saat ini dilakukan adalah mengambil jalan pintas sebagai upaya yang lebih baik ketimbang menempuh tata cara yang menyulitkan sebagaimana yang tercantum dalam peraturan hukum tersebut. Namun, bagi warga yang terpenting adalah perlakuan yang diterima oleh aparat pemerintah terhadap tanahnya secara umum hanya akan merugikan, sebab warga memiliki ukuran yang didalamnya terkait dengan berbagai kepentingan

${ }^{25}$ Abdurrahman, Op. Cit., hal. 138.

${ }^{26}$ Pro Justitia, Op. Cit, hal. 28.

${ }^{27}$ Abdurrahman, Op. Cit, hal.1 41. 
mengenai nilai dari tanah tersebut, sehingga ada nilai yang bersifat faktual dan ideal.

Apa yang dipersoalkan dalam pembebasan tanah tidak mungkin melewati kedua nilai tersebut, yang terjadi justru berada di bawah nilai faktual tersebut. Ironisnya, warga masih dituntut untuk berkorban memberikan pengorbanan berupa kerelaan menurunkan permintaannya dari nilai faktual yang ada. Nilai faktual saja bagi warga sudah tidak cukup apalagi jika nilainya di bawah nilai faktual tersebut.

Warga ingin agar nilai faktual ditetapkan secara ideal dan adil, dimana penentuannya sesuai dengan selera warga yang kadangkadang sangat jauh di atas nilai faktual. Sebab alasan bagi warga adalah bukan hanya tanah semata, akan tetapi menyangkut segala macam aspek yang terkait dengan tanah tersebut termasuk berbagai nilai lebih yang memang sulit dinilai dengan uang. Hal ini bagi Pemerintah merupakan sesuatu yang "keterlaluan" dan tidak mungkin untuk dipenuhi. ${ }^{28}$

Menurut pendapat karyawan BPN Pusat, dalam prakteknya dilapangan pernah terjadi tuntutan ke Pengadilan oleh para Pemegang Hak Atas Tanah (masyarakat) yang tanahnya tergusur karena karena pemilik tanah tidak menerima harga ganti rugi yang disepakati atau adanya klaim terhadap tanah-tanah yang telah dibebaskan, tuntutan akan sertifikat ganda, dan tuntutan akan kesalahan bayar.

Pengertian ganti rugi ini menuntut UU No. 20 Tahun 1961 hingga Keppres No.55 tahun 1993, jika dilihat dari materinya secara substansial adalah sama saja. Yaitu berupa ganti rugi hak atas tanah, bangunan, tanaman dan benda-benda lain yang berkaitan dengan tanah, yang bentuknya dapat berupa uang, tanah pengganti, pemukiman kembali dan bentuk-bentuk ganti rugi yang lainnya yang disetujui oleh pihak-pihak yang bersangkutan. Tampaknya ganti rugi itu diartikan sebagai penggantian atas harga fisiknya (materi) tanah berikut bangunan di atasnya.

Pada prinsipnya adanya pemberian ganti rugi di samping menggunakan asas musyawarah, inilah yang membedakan dengan tindakan perampasan tanah secara paksa. Juga sekaligus menunjukkan adanya perlindungan dan penghormatan terhadap

${ }^{28}$ Abdulrahman, "Masalah Pencabutan Hak-hak atas tanah, Pembebasan Tanah dan Pengadaan Bagi Pelaksanaan Pembangunan untuk Kepentingan Umum", (Bandung: Citra Aditya Bakti, 1996), hal. 3. 
hak tanah rakyat. Namun penghormatan dan perlindungan terhadap hak tersebut seperti yang dituliskan secara umum dalam berbagai peraturan pengadaan tanah adalah sangat tergantung dari seberapa besar ganti rugi, dan bagaimana cara yang digunakan dalam menggusur tanah rakyat.

Selain itu apakah ganti ruginya sudah diberikan dengan jumlah yang senilai dengan nilai yang mampu dipancarkan oleh tanah itu, ataukah sebatas ganti rugi fisik semata. Praktek di lapangan inilah yang akan menilai sejauhmana penghormatan dan perlindungan terhadap hak-hak rakyat telah dilakukan dengan bijaksana dan adil, sebagaimana yang diamanatkan oleh Pasal 33 UUD 1945 dan Undang-Undang Pokok Agraria (UUPA).

Berdasarkan pendapat karyawan BPN Pusat, penetapan besarnya ganti rugi tanah sudah sesuai dengan peraturan yang berlaku yakni Keppres No.55 Tahun 1993, demikian juga menurut Badan Hukum Appraisal Independent. Sebab dalam Keppres No.55 tahun 1993 secara jelas disebutkan bahwa musyawarah dilaksanakan secara langsung antara instansi Pemerintah yang memerlukan tanah dengan para pemegang hak atas tanah dan pemilik bangunan, tanaman, dan benda-benda lain yang terkait dengan tanah yang bersangkutan. ${ }^{29}$ Nilai tanah berdasarkan nilai nyata atau sebenarnya dengan memperhatikan NJOP tahun terakhir untuk tanah yang bersangkutan. ${ }^{30}$

Masih berdasarkan hasil wawancara dengan karyawan BPN Pusat, dikatakan bahwa bentuk dan jenis ganti rugi tanah warga yang mengalami pembebasan biasanya berupa Ruislag/tanah tukar, jalan pengganti, dan bentuk lainnya dari penggantian berupa fasilitas sosial. Sehingga antara implementasi di lapangan dengan ketentuan yang berlaku terhadap bentuk dan jenis ganti rugi tanah sudah sama.

Pemegang hak atas tanah dan pemilik bangunan, tanaman dan benda benda lain yang terkait dengan tanah yang bersangkutan atau wakil yang ditunjuk menyampaikan keinginannya mengenai bentuk dan besarnya ganti rugi. ${ }^{31}$ Ganti rugi diupayakan dalam bentuk yang tidak menyebabkan perubahan terhadap pola hidup

\footnotetext{
${ }^{29}$ Peraturan Menteri Negara Agraria/Kepala BPN No.l tahun 1994, Pasal 14 ayat (1).

${ }^{30}$ Ibid, Pasal 16 ayat (1) butir a.

${ }^{31}$ Ibid, Pasal 16 ayat (2).
} 
masyarakat dengan mempertimbangkan kemungkinan dilaksanakannya alih pemukiman ke lokasi yang sesuai. ${ }^{32}$ Besarnya uang santunan sebagaimana dimaksud dalam ayat 1 ditetapkan oleh Panitia menurut pedoman yang ditetapkan oleh Bupati/ walikotamadya. ${ }^{33}$

Dengan demikian dari dua ketentuan di atas, asas dan bentuk serta jenis ganti rugi dalam peraturan tersebut dapat berupa:

1. Hasil musyawarah antar kedua belah pihak berdasarkan Asas Musyawarah untuk Mufakat;

2. Uang, tanah pengganti, pemukiman kembali, gabungan dari kedua atau ketiganya, dan bentuk lain yang disetujui oleh pihak-pihak yang bersangkutan;

3. Uang santunan.

Sedangkan Badan Hukum Appraisal Independent bertugas untuk menaksir tanah dan harganya, sehingga nantinya besaran ganti rugi tersebut bisa meminimasi kekecewaan para pemegang hak atas tanah. Namun bila besarnya ganti rugi tersebut masih mengindikasikan adanya ketidakadilan bagi para warga selaku pemegang hak atas tanah juga ketidakadilan bagi pihak Pemerintah (atau pihak-pihak yang menginginkan tanah tersebut) maka kedua belah pihak dapat melakukan musyawarah kembali atau melibatkan Badan Hukum Appraisal Independent sebagai pihak ketiga (pihak penengah). Sebab berdasarkan pendapat dari warga (masyarakat) yang pernah mengalami masalah pembebasan tanah, pelaksanaan ganti rugi tanah belum sesuai dengan harapan mereka baik itu dari segi proses penggantiannya, besarnya ganti rugi tersebut (jika dalam bentuk nominal), hingga realisasi dari bentuk ganti rugi yang dijanjikan oleh Pemerintah atau yang disepakati kedua belah pihak (Pemerintah dan warga).

Jika tanah berfungsi sebagai wadah untuk perumahan yang merupakan tempat bernaung, maka tentu saja warga (masyarakat) beranggapan bahwa tanah merupakan harta yang paling berharga bagi keluarga, sehingga masalah ganti rugi hendaknya sesuai dengan harapan warga.

\footnotetext{
${ }^{32}$ Ibid, Pasal 16 ayat (4).

${ }^{33}$ Ibid, Pasal 20 ayat (2).
} 


\section{Tanggung Jawab PT. Lapindo Brantas Terhadap Dampak Semburan Lumpur di Sidoardjo}

PT Lapindo Brantas Inc yang memiliki ijin dari pemerintah untuk melakukan kegiatan pengeboran sumber daya alam di Blok Brantas termasuk di daerah Sidoardjo, adalah salah satu anak perusahaan group Bakrie. Lapindo Brantas, Inc. dibentuk pada tahun 1996 dengan membeli saham milik HUFFCO dan menjadi operator kontrak bagi hasil Blok Brantas, Jawa Timur.

Pada tahun 2004, Novus menjual kepemilikannya di Lapindo. Penjualan saham tersebut mengubah komposisi kepemilikan Lapindo menjadi PT Medco E \&P Brantas (32\%), dan Santos (Brantas) Pty, Ltd (18\%). Sisanya, dikuasai PT Energi Mega Persada. Group Bakrie memiliki $70 \%$ saham di PT Energi Mega Persada Tbk, selebihnya 30 $\%$ kepemilikan sahamnya adalah merupakan milik publik. PT Energi Mega Persada Tbk menanamkan sahamnya di Kalila Energi Ltd dan Pan Asia Ent Ltd. Saham di masing-masing perusahaan tersebut sebesar 99\% adalah milik PT Energi Mega Persada Tbk Kedua perusahaan terakhir inilah yang memiliki saham di PT Lapindo Brantas Inc dengan perbandingan saham di Kalila Energi Ltd 85\% dan $15 \%$ adalah saham yang ditanamkan oleh Pan Asia Enterprise Ltd.

PT. Energi Mega Persada sebagai pemilik saham mayoritas Lapindo Brantas merupakan anak perusahaan Grup Bakrie. Grup Bakrie memiliki $63,53 \%$ saham, sisanya dimiliki komisaris PT. Energi Mega Persada, Rennier A.R. Latief, dengan 3,11\%, Julianto Benhayudi $2,18 \%$, dan publik $31,18 \%$. Chief Executive Officer (CEO) Lapindo Brantas Inc. adalah Nirwan Bakrie yang merupakan adik kandung dari pengusaha dan Menteri Koordinator Bidang Kesejahteraan Rakyat Republik Indonesia pada Kabinet Indonesia Bersatu, Aburizal Bakrie. ${ }^{34}$

Perusahaan yang menanamkan saham untuk melakukan pengelolaan pengeboran sumber daya alam di Blok Brantas dengan production sharing contrac adalah PT Lapindo Brantas Inc (5\%), PT Medco E\&P Brantas (32\%) dan Santos Brantas Pty Ltd (18\%). Lokasi blok Brantas di Jawa Timur dengan luas sebesar 3050 kilometer persegi, sumur produksinya terdapat di Wunut, Carat, Tanggulangin dan Porong.

PT Lapindo Brantas Inc selain sebagai pemilik saham terbesar pengeboran di Blok Brantas, adalah juga yang menjadi operator

${ }^{34}<$ http://idwikipadia.org/wiki/Iapindo_Brantas>. diakses tanggal 24 Juni 2005. 
pengeboran, sedangkan Medco dan Santos tidak mempunyai andil dalam operasi pengeboran. Bencana semburan Lumpur panas di daerah Sidoardjo terjadi karena adanya kesalahan prosedur dalam pelaksanaan pengeboran, maka PT Lapindo Brantaslah yang paling bertanggung jawab atas kerusakan lingkungan hidup serta dampaknya di daerah Sidoardjo, kecuali kalau bisa dibuktikan tidak teijadi kesalahan dalam prosedur operasi pengeboran.

PT Medco E\&P Brantas dan Santos Pty Ltd tidak mau bertanggung jawab, terbukti dengan adanya rencana PT Medco untuk mengajukan gugatan abritrase terhadap PT Lapindo Brantas Inc karena dinilai melanggar sejumlah kesepakatan kerja. Dalam peijanjian kerja yang ditandatangani pada tahun 1992, juga disebutkan bahwa anak perusahaan PT Medco Energi Intemasional Thk itu tidak termasuk pihak yang bertanggung jawab bila terjadi musibah pada ladang gas tersebut. Rencana gugatan abritrase tersebut kemudian dibatalkan setelah ada kesepakatan dengan PT LPI bahwa Medco tidak menanggung biaya akibat semburan lumpur tersebut. ${ }^{35}$

Tragedi Lumpur Lapindo dimulai pada tanggal 27 Mei 2006. Peristiwa ini menjadi suatu tragedi ketika banjir lumpur panas mulai menggenangi areal persawahan, pemukiman penduduk dan kawasan industri. Hal ini wajar mengingat volume lumpur diperkirakan sekitar 5.000 hingga 50 ribu meter kubik perhari (setara dengan muatan penuh 690 truk peti kemas berukuran besar).

Akibatnya, semburan lumpur ini membawa dampak yang luar biasa bagi masyarakat sekitar maupun bagi aktivitas perekonomian di Jawa Timur: genangan hingga setinggi 6 meter pada pemukiman; total warga yang dievakuasi lebih dari 8.200 jiwa; rumah/tempat tinggal yang rusak sebanyak 1.683 unit; areal pertanian dan perkebunan rusak hingga lebihdari 200 ha; lebih dari 15 pabrik yang tergenang menghentikan aktivitas produksi dan merumahkan lebih dari 1.873 orang; tidak berfiingsinya sarana pendidikan; kerusakan lingkungan wilayah yang tergenangi; rusaknya sarana dan prasarana infrastruktur (jaringan listrik dan telepon); terhambatnya ruas jalan tol Malang Surabaya yang berakibat pula terhadap aktivitas produksi di kawasan Ngoro (Mojokerto) dan Pasuruan yang selama ini merupakan salah satu kawasan industri utama di Jawa Timur. ${ }^{36}$

\footnotetext{
${ }^{35}$ Majalah Trust, No 5 Takm V. 20 - 26 November 2006.

${ }^{36}$ Kompas, 19 Juni 2006.
} 
Memperhatikan bahwa semburan lumpur panas yang terjadi karena adanya kegiatan pengeboran sumber alam yang dilakukan oleh PT. Lapindo Brantas Inc,dan sementara disimpulkan bahwa kecelakaan tersebut adalah karena kelalaian prosedur pengeboran karena tidak dipasangnya selubung bor (chasing) dan bukan merupakan akibat adanya bencana alam, maka PT. Lapindo Brantas bersedia bertanggung jawab terhadap dampak yang ditimbulkan.

Pimpinan Bakrie Group menyatakan bahwa kesediaannya bertanggung jawab adalah karena terkait pada tanggung jawab sosial korporasi (Social corporate responsibility). Prinsip tanggung jawab sosial dan lingkungan ini diatur dalam bab V Pasal 74 Undang-Undang No 40 Tahun 2007 sebagai berikut:

(1) Perseroan yang menjalankan kegiatan usahanya di bidang dan/atau berkaitan dengan sumber daya alam wajib melaksanakan TanggungJawab Sosial dan Lingkungan.

(2) Tanggung Jawab Sosial dan Lingkungan sebagaimana dimaksud pada ayat (1) merupakan kewajiban Perseroan yang dianggarkan dan diperhitungkan sebagaimana biaya Perseroan yang pelaksanaannya dilakukan dengan memperhatikan kepatutan dan kewajaran.

(3) Perseroan yang tidak melaksanakan kewajiban sebagaimana dimaksud pada ayat (1) dikenai sanksi sesuai dengan ketentuan peraturan perundangundangan.

(4) Ketentuan lebih lanjut mengenai Tanggung Jawab Sosial dan Lingkungan diatur dengan Peraturan Pemerintah.

Berkaitan dengan hal tersebut, dengan memperhatikan kerusakan lingkungan hidup dan dampak sosial, ekonomi yang ditimbulkannya Pemerintah telah mengeluarkan Keputusan Presiden No 13 tahun 2006 mengenai pembentukan Tim Penanggulangan Lumpur Sidoardjo yang sekarang sudah digantikan oleh Peraturan Pemerintah No 14 Tahun 2007 menjadi Badan Penanggulangan Lumpur Sidoardjo. Dasar pertimbangan dikeluarkan PP No. 14 Tahun 2007 yaitu: 
i. Bahwa dampak luapan lumpur di Sidoarjo sudah demikian luas terhadap sendi-sendi kehidupan masyarakat di sekitarnya, perlu kebijakan nasional yang lebih komprehensif.

ii. Bahwa dalam rangka melanjutkan langkah-langkah penyelamatan penduduk, penanganan masalah sosial dan infrastruktur di sekitar bencana akibat luapan Lumpur di Sidoarjo, perlu peningkatan penanganan masalah dimaksud, dengan memperhitungkan risiko lingkungan yang terkecil.

iii. Bahwa berdasarkan pertimbangan sebagaimana dimaksud dalam huruf a dan $b$, dan sehubungan berakhirnya masa tugas Tim Nasional Penanggulangan Semburan Lumpur di Sidoarjo, maka dipandang perlu membentuk Badan Penanggolangan Lumpur Sidoarjo.

Menurut hasil tim kajian semburan Lumpur panas di Sidoardjo yang dibentuk Komnas HAM, Lumpur panas telah membuat warga Porong dan sekitarnya tercabut haknya. Di antaranya hak atas lingkungan yang sehat, hak atas pekerjaan dan hak untuk memperoleh informasi. ${ }^{37}$

Seberapa jauh perseroan harus bertanggung jawab atas kesalahan yang dilakukan, landasannya tercantum dalam UU No. 1 Tahun 1995 yang kemudian diubah menjadi Undang-Undang No 40 Tahun 2007, seperti yang telah diuraikan sebelumnya. Menurut undang-undang tersebut dinyatakan bahwa tanggung jawab perseroan dilaksanakan oleh direksi, besarnya ganti rugi oleh perusahaan sebatas kekayaan perusahaan tersebut, kecuali apabila dapat dibuktikan adanya unsur pelanggaran dan kelalaian dalam melaksanakan tugasnya, maka tanggung jawab akan sampai pada harta pribadinya.

Tanggung jawab pemegang saham sesuai pengaturan dalam Pasal 3 hanya bertanggung jawab terbatas sampai dengan besarnya saham yang dimilikinya. Namun dengan adanya doktrin piercing the corporate veil, apabila yang kelalaian yang dilakukan diketahui oleh pemegang saham, maka prinsip tanggung jawab terbatas menjadi tanggung jawab tidak terbatas.

Bagi masyarakat yang dirugikan, PT LPI bertanggung jawab dengan memberikan biaya hidup dan uang kontrak rumah selama 2 tahun. Selanjutnya PT LPI juga memberikan ganti rugi terhadap harta benda penduduk berupa tanah, sawah, kebun yang dimiliki, serta pemberian ganti rugi bagi perusahaan yang terkena dampak tersebut.

${ }^{37}$ Tempo Edisi 27 November - 3 Desember 2006. 
Sesuai dengan pengaturan dalam Peraturan Pemerintah No 14 Tahun 2007 Tentang Pembentukan Badan Penanggulangan Lumpur Sidoardjo, pemberian ganti rugi diatur sebagai berikut:

1. Dalam rangka penanganan masalah sosial kemasyarakatan, PT Lapindo Brantas membeli tanah dan bangunan masyarakat yang terkena luapan lumpur Sidoarjo dengan pembayaran secara bertahap, sesuai dengan peta area terdampak tanggal 22 Maret 2007 dengan akta jual-beli bukti kepemilikan tanah yang mencantumkan luas tanah dan lokasi yang disahkan oleh Pemerintah.

2. Pembayaran bertahap yang dimaksud, seperti yang telah disetujui dan dilaksanakan pada daerah yang termasuk dalam peta area terdampak 4 Desember 2006, 20\% (dua puluh perseratus) dibayarkan di muka dan sisanya dibayarkan paling lambat sebulan sebelum masa kontrak rumah 2 (dua) tahun habis.

3. Biaya masalah sosial kemasyarakatan di luar peta area terdampak tanggal 22 Maret 2007, setelah ditandatanganinya Peraturan Presiden ini, dibebankan pada APBN.

4. Peta area terdampak sebagaimana dimaksud pada ayat (1) dan ayat (3) adalah sebagaimana tercantum dalam Lampiran Peraturan Presiden ini.

5. Biaya upaya penanggulangan semburan lumpur termasuk di dalamnya penanganan tanggul utama sampai ke Kali Porong dibebankan kepada PT Lapindo Brantas.

6. Biaya untuk upaya penanganan masalah infrastruktur termasuk infrastruktur untuk penanganan luapan lumpur di Sidoarjo, dibebankan kepada APBN dan sumber dana lainnya yang sah.

Dalam kasus semburan lumpur PT. Lapindo Brantas, perhitungan Greenomics menyebutkan kerugian yang harus diganti bisa mencapai angka $\mathrm{Rp} 33,27$ triliun. Terdiri dari biaya penanganan sosial, pembersihan lumpur, ekologi, dampak pada pertumbuhan ekonomi, pemulihan bisnis dan ekonomi, biaya kehilangan kesempatan (jangka waktu sangat pendek) dan ketidakpastian ekonomi akibat eskalasi dampak

Kerugian tersebut masih bisa lebih besar, terutama jika terjadi eskalasi dampak turunan lebih luas lagi dalam jangka menengah dan panjang. Besarnya nilai keingian diakibatkan karena adanya floating time (waktu mengambang atau ketidakpastian) penanganan semburan lumpur tersebut. 
Perusahaan yang juga terkena dampak semburan lumpur, maka PT Minarak Lapindo Jaya (MLJ) akhirnya bersedia segera memberikan uang muka ganti rugi senilai $\mathrm{Rp} 42,7$ miliar kepada delapan perusahaan korban lumpur dari sebanyak 23 perusahaan yang menjadi korban Lumpur Lapindo itu.

Delapan perusahaan yang akan menerima pembayaran ganti rugi tersebut adalah Melina Dewi, Andrian Zulkarnain, CV Karya Kasih Karunia, PT Supra Surya Indo, PT Srikaya Putra Mas, PT Yamaindo Perkasa, PT Victory Rotanindo, dan CV Airlangga Mebelindo Desain.

Pembayaran ganti rugi untuk pengusaha ini ada tiga tahap. Tahap pertarna adalah pembayaran uang muka sebesar 20 persen yang akan dibayarkan pada awal bulan Juni 2007 ini, kemudian tahap kedua 10 persen.

Pembayaran tahap kedua ini khusus dibayarkan kepada perusahaan yang masih mempunyai hutang di luar, sehingga bukan pengusaha yang menerima tetapi pihak pengutangnya yang menerima. Pembayaran tahap kedua ini akan dibayar pada awal bulan Juli tahun ini juga. Kemudian pembayaran tahap ketiga sebesar 70 persen, dan akan dibayarkan antara bulan Mei sampai Desember tahun 2008.

Namun, PT MLJ tidak mau menyebutkan berapa jumlah masingmasing perusahaan Yang akan dibayarkan dengan, karena tidak diijinkan oleh pengusaha korban lumpur. Dari delapan perusahaan yang akan mendapat pencairan ganti rugi ini total nilai yang harus dibayar Lapindo sebesar Rp 42,7 miliar.

Perusahaan yang mengidaim paling banyak menerima ganti rugi adalah PT Supra Surya Indo, sedangkan yang paling kecil menerima ganti rugi itu adalah Melina Dewi.

Pembayaran tersebut merupakan pembayaran tahap pertama sebesar $20 \%$, dan pembayaran selanjutnya akan dilakukan secara bertahap. Pada kenyataannya di lapangan masih banyak hal-hal yang berjalan tidak mulus, berupa ketidak sesuaian data status dan luasnya tanah penduduk serta meluasnya luberan lumpur melampaui batas peta yang telah disepakati untuk pemberian ganti rugi.

Status tanah masyarakat yang juga menjadi masalah adalah bahwa tidak semua kepemilikan tanah dapat dibuktikan dengan sertifikat, karena belum adanya kesadaran penduduk untuk mengurus sertifikat tanah, sehingga masih banyak penduduk desa yang hanya memiliki surat pethok yang tidak terdaftar di Badan Pertanahan Nasional. Pemerintah menunjuk Badan Pertanahan Nasional dan Bupati Sidoardjo untuk menentukan kepemilikan yang sah Hal tersebut membuat pemberian ganti rugi tertunda karena harus dilakukan 
penelitian yang cermat agar di kemudian hari tidak timbul masalah. Hal-hal tersebut membuat adanya protes dari penduduk yang terkena dampak semburan lumpur tersebut yang harus diselesaikan oleh kedua belah pihak dan pemerintah daerah serta Badan penanggulangan lumpur Sidoardjo.

\section{Kerusakan Lingkungan Hidup Akibat Pengeboran PT. Lapindo Brantas di Sidoardjo}

Pada kasus pengeboran di Sidoardjo ini, dokumen Amdal masih dalam proses dan belum diperoleh oleh PT Lapindo Brantas, Meskipun sudah memiliki konsesi dari Pemerintah dan production sharing contract di Blok Brantas. Kegiatan pengeboran dilakukan hanya berbekal ijin Upaya Pengelolaan Lingkungan (UKL) dan Upaya Pemantauan Lingkungan (UPL) dari Kementrian Lingkungan Hidup. Ijin ini tidak prinsip karena cakupannya sangat sederhana dan tidak terlalu teknis.

Dalam pengeboran migas ada dua perijinan terkait lingkungan, yaitu eksplorasi dan eksploitasi. Pada eksploitasi blok maka risikonya dikelola lewat dokumen-dokumen dan perencanaan yang disebut sebagai Amdal, REX dan RPL. Sedangkan pada eksplorasi risikonya dikelola oleh dokumen yang disebut UKL dan UPL saja. Untuk sumur banjar panji dalam kasus Lapindo, termasuk eksplorasi bukan eksploitasi, walaupun di dalam blok eksploitasi.

Pengeboran yang dilakukan dengan kedalaman lebih dari 9000 meter di sumur Banjar Panji 1 tersebut sudah bukan eksplorasi melainkan sudah tahap eksploitasi. Dengan demikian dapat dikatakan bahwa kegiatan pengeboran yang dilakukan itu terlalu cepat dilaksanakan karena belum diperolehnya dokumen amdal yang seharusnya kajiannya dilakukan dengan benar dan tepat.

Bencana luapan lumpur panas di Sidoardjo, tanpa harus dibuktikan lagi telah menimbulkan kerusakan lingkungan hidup yang sangat hebat. Pencemaran dan kerusakan lingkungan yang disebutkan pada pasal 1 butir 12 dan 14 UUPLH terjadi di sekitar pengeboran Banjar Panji 1.

Pada awal terjadi luapan menurut Drs. Latief Burhan MS, Ketua Dewan Lingkungan Hidup (DLH) Jawa Timur menjelaskan, kerusakan lahan subur ini terindikasi hingga saat ini, lahan sawah yang tergenang lumpur panas akan berpotensi semakin meluas, sesuai topografi wilayah. Ukuran partikel lumpur jauh lebih kecil dibanding partikel tanah pertanian subur, sehingga partikel-partikel tersebut dapat 
mengisi rongga (voids) tanah yang berisi udara dan air, padahal rongga dalam tanah sangat diperlukan untuk aliran air tanah, hara-mineral dan oksigen.

Dengan penutupan rongga (plugging) tersebut oleh lumpur, maka tanah sawah tidak dapat ditanami lagi, atau memerlukan waktu yang lama untuk memulihkan mutu dan struktur tanah seperti semula. Dampak lingkungan ini akan menimbulkan masalah sosial ekonomi masyarakat yang menggantungkan hidupnya pada lahan sawah tersebut, dalam jangka pendek dan menengah.

Sedangkan kerusakan air tanah maupun air permukaan berpotensi terjadi di sekitar lokasi semburan lumpur, apalagi sungai Porong berjarak kurang lebih $3 \mathrm{~km}$ dari pusat semburan lumpur panas. Air sebagai sumber kehidupan wajib dilindungi karena merupakan kebutuhan dasar penduduk di sekitarnya, oleh karena itu pemulihan sumber air dan ekosistem perairan, sebagai akibat dari lumpur panas itu harus diprioritaskan.

Kandungan air yang berada di dalam Lumpur berkisar antara 4070 $\%$ dengan kadar garam $\mathrm{NaCL}$ yang sangat tinggi, sehingga air sumur penduduk yang selama ini bisa digunakan untuk mandi, cuci bahkan untuk bahan baku air minum dapat berubah menjadi air payau.

Apa yang dikemukakan tersebut dikemukakan pada awal terjadinya bencana sekarang setelah satu tahun lebih semburan terjadi dan belum bisa dihentikan. Maka dampak yang ditimbulkan semakin parah, karena area yang terendam semakin meluas.

Peraturan pertanggung jawaban korporasi diatur dalam undangundang Negara Republik Indonesia. Pada Undang-Undang No 4 Tahun 1982 (UULH) sudah diatur mengenai prinsip tanggung jawab korporasi. Azas tanggung jawab mutlak terdapat dalam pasal 21 UULH, yang berbunyi:

Dalam beberapa kegiatan yang menyangkut jenis sumber daya tertentu tanggung jawab timbul secara mutlak pada perusak dan atau pencemar pada saat terjadinya perusakan dan pencemaran lingkungan hidup yang pengaturanya diatur dalam peraturan perundang-undangan yang bersangkutan.

Penjelasannya adalah sebagai berikut:

Tanggung jawab mutlak dikenakan secara selektif atas kasus yang akan ditetapkan berdasarkan peraturan perundangundangan yang dapat menentukan jenis dan 
kategori kegiatan yang akan terkena oleh ketentuan termaksud.

Penyusun UULH menyadari sepenuhnya bahwa azas tanggung jawab mutlak dengan pembalikan beban pembuktian tidak begitu saja dapat diterapkan. Oleh karena itu, maka kata-kata yang digunakan adalah "dalam beberapa kegiatan" dan "menyangkut jenis sumber daya tertentu", yang penentuannya akan diatur dalam peraturan perundangundangan. Dengan demikian, maka penerapan azas tanggung jawab mutlak dilaksanakan secara bertahap, sesuai dengan perkembangan kebutuhan.

Dalam hubungannya dengan penyelesaian ganti kerugian sebagaimana konsekuensi tanggung jawab, ketentuan yang lazim dipakai adalah sebagaimana tertera dalam Kitab Undang-Undang Hukum Perdata, yaitu Pasal 1243 dan Pasal 1365.

Pasal 1243 menyatakan sebagai berikut:

Penggantian biaya, rugi dan bunga karena tak dipenuhinya suatu perikatan, barulah mulai diwajibkan, apabila si berutang, setelah dinyatakan lalai memenuhi perikatannya, tetap melalaikannya, atau jika sesuatu yang hams diberikan atau dibuatnya hanya dapat diberikan atau dibuat dalam tenggang waktu yang telah dilampaukannya. ${ }^{38}$

Pasal 1365 menyatakan:

Tiap perbuatan melanggar hukum, yang membawa kerugian kepada seorang lain, mewajibkan orang yang karena salahnya menerbitkan kerugian itu, mengganti kerugian tersebut. ${ }^{39}$

Prinsip yang digunakan dalam kedua pasal tersebut adalah liability based on fault dengan beban pembuktian yang memberatkan penderita baru akan memperoleh ganti kerugian apabila ia berhasil membuktikan adanya unsur kesalahan pada pihak tergugat. Kesalahan di sini merupakan unsur yang menentukan pertanggung jawaban, yang berarti bila tidak terbukti adanya kesalahan, tidak ada kewajiban memberi ganti kerugian.

38 Subekti R \& R Tjitrosudibio, Kitab Undang-undang Hukum Perdata, (Jakarta, Pradnya Paramita, 1985), hal. 45.

${ }^{39}$ Ibid. 
Dalam hal menuntut ganti kerugian berhubungan dengan penderitaan akibat perusakan dan atau pencemaran, pasal yang dapat digunakan adalah Pasal 1365 KUH Perdata. Pasal 1365 KUHPerdata menentukan syarat-syarat untuk menentukan perbuatan melawan hukum. Pertama, harus ada perbuatan melawan hukum, yaitu tidak hanya perbuatan yang bertentangan dengan UU, tetapi berbuat atau tidak berbuat yang melanggar hak orang lain atau bertentangan dengan kewajiban orang yang berbuat atau tidak berbuat, bertentangan dengan sifat berhati-hati sebagaimana patutnya dalam masyarakat. Kedua, ada kesalahan. Ketiga, ada kerugian. Keempat, ada hubungan sebab akibat antara perbuatan melawan hukum itu dan kerugian. Selanjutnya, Pasal 1366 KUHPerdata menyatakan "setiap orang bertanggungjawab tidak saja untuk kerugian yang disebabkan karena perbuatannya, tetapi juga untuk kerugian yang disebabkan karena kelalaian atau kurang hatihatinya". Pasal 1367 KUHPerdata mengatur "seorang tidak saja bertanggungjawab untuk kerugian yang disebabkan karena perbuatannya sendiri, tetapi juga untuk kerugian yang disebabkan karena perbuatan orang-orang yang menjadi tanggungannya, atau disebabkan oleh barang-barang yang berada di bawah pengawasannya".

Wujud ganti rugi akibat perbuatan melawan hukum, orang lain jadi rugi. Jadi, pihak yang melakukan perbuatan melawan hukum wajib bertanggung jawab atas kerugian yang diderita oleh orang lain tersebut.

Berdasarkan uraian di atas, dapat disimpulkan bahwa setiap tindakan pihak yang termasuk perbuatan melawan hukum yang mengakibatkan kerugian kepada pihak lainnya, maka secara hukum dapat dimintai pertanggungjawaban secara perdata dengan mengajukan gugatan ke pengadilan. Karena itu, korban lumpur Lapindo mempunyai alasan hak, dasar dan alasan hukum menuntut dan meminta pertanggungjawaban secara perdata terhadap pihak-pihak karena perbuatan melawan hukum, dan kesalahannya mengakibatkan timbulnya lumpur Lapindo dengan mengajukan gugatan perdata tentang perbuatan melawan hukum dengan menuntut ganti kerugian. Tak perlu diperhatikan apakah penyebabnya karena disengaja atau karena kelalaian. Tanggung jawab perdata dan ganti kerugian yang wajib dipikul oleh pihak yang melakukan perbuatan melawan hukum hanya sebatas kerugian langsung dari perbuatan melawan hukum.

Dalam kaitan dengan pembuktian perlu dikemukakan Pasal 1865 KUH Perdata, yang menyatakan, bahwa barangsiapa mengajukan peristiwa-peristiwa atas nama ia mendasarkan sesuatu hak, diwajibkan 
membuktikan peristiwa-peristiwa itu; sebaliknya barang siapa mengajukan peristiwa-peristiwa guna pertahanan hak orang lain diwajibkan juga membuktikan peristiwa peristiwa itu.

Rudiger Lummert mengemukakan, bahwa dengan berkembangnya industrialisasi yang menghasikan resiko yang bertambah besar serta makin rumitaya hubungan sebab-akibat, maka teori hukum telah meninggalkan konsep "kesalahan" dan berpaling ke konsep "resiko". Perkembangan industri modern telah membawa serta sejumlah resiko yang terjadi setiap hari, yang tidak dapat dihindarkan dari sudut ekonomi. la telah menimbulkan derita dan bagi si penderita hal tersebut tidak dapat ditanggungnya tanpa suatu ganti kerugian. ${ }^{40}$

Undang-Undang No 23 Tahun 1997, juga mengatur pertanggungjawaban korporasi atas pencemaran dan kerusakan lingkungan hidup yang ditimbulkan atas kegiatan usahanya. Sesuai dengan Pasal 35 Undang-Undang No 23 tahun 1997 tentang Pengelolaan Lingkungan Hidup dikenal adanya tanggung jawab mutlak bagi penanggung jawab usaha yang kegiatannya menimbulkan dampak besar terhadap lingkungan hidup, dalam pasal35 diatur tentang tanggung jawab mutlak korporasi. Pasal 35 UUPLH menyatakan:

(1) Penanggung jawab usaha dan/atau kegiatan usaha dan kegiatannya menimbulkan dampak besar dan penting terhadap lingkungan hidup, yang menggunakan bahan berbahaya dan beracun, dan/atau menghasikan limbah bahan berbahaya dan beracun, bertanggung jawab secara mutlak atas kerugian yang ditimbulkan, dengan kewajiban membayar ganti rugi secara langsung dan seketika pada saat terjadinya pencemaran dan/atau perusakan lingkungan hidup.

(2) Penanggung jawab usaha dan/usaha kegiatan dapat dibebaskan dari kewajiban membayar ganti rugi sebagaimana dimaksud pada ayat (1) jika yang bersangkutan dapat membuktikan bahwa pencemaran dan/atau perusakan lingkungan hidup disebabkan salah satu alasan dibawah ini:

a. adanya bencana alam dan peperangan; atau

${ }^{40}$ Kusnadi Hardjosumantri, Loc. Cit. 
b. adanya keadaan terpaksa di luar kemampuan manusia atau

c. adanya tindakan pihak ketiga yang menyebabkan terjadinya pencemaran dan/atau perusakan lingkungan hidup.

(3) Dalam hal terjadi kerugian yang disebabkan oleh pihak ketiga sebagaimana dimaksud pada ay at (2) huruf $c$, pihak ketiga bertanggung jawab membayar ganti rugi.

Penjelasan Pasal35 ayat 1:

Pengertian bertanggung jawab secara mutlak atau strict liability, yakni unsur kesalahan tidak perlu dibutuhkan oleh pihak penggugat sebagai dasar pembayaran ganti kerugian. Ketentuan ayat ini merupakan lex specialis dalam gugatan melanggar hukum pada umumnya. Besarnya ganti rugi yang dapat dibebankan terhadap pencemar atau perusak lingkungan hidup menurut pasal ini dapat ditetapkan sampai batas tertentu. Yang dimaksudkan sampai batas tertentu adalah jika menurut penetapan peraturan perundang-undangan yang berlaku, ditentukan keharusan asuransi bagi usaha dan/atau kegiatan yang bersangkutan atau telah tersedia dana lingkungan hidup.

Penjelasan Pasal 35 ayat 3 menyatakan bahwa yang dimaksud dengan tindakan pihak ketiga dalam ayat ini merupakan persaingan curang atau kesalahan yang dilakukan Pemerintah. Ketentuan pidana berkaitan dengan tanggung jawab korporasi (corporate liability), diatur dalam Pasal 45 dan Pasal 46 UUPLH.

\section{Pasal 45:}

Jika tindak pidana sebagaimana dimaksud dalam bab ini dilakukan oleh atau atas nama suatu badan hukum, perseroan, perserikatan, yayasan atau organisasi lain, ancaman pidana denda diperberat dengan sepertiga.

Pasal 46:

(1) Jika tindak pidana sebagaimana dimaksud dalam Bab ini dilakukan oleh atau atau atas nama badan hukum, perseroan, perserikatan, yayasan atau organisasi lain, tuntutan pidana dilakukan dan sanksi pidana dan 
tindakan tata tertib sebagaimana dimaksud dalam Pasal 47 dijatuhkan baik terhadap badan hukum, perseroan, perserikatan, yayasan atau organisasi lain tersebut maupun terhadap mereka yang memberi perintah untuk melakukan tindak pidana tersebut atau yang bertindak sebagai pemimpin dalam perbuatan itu atau terhadap kedua-duanya.

(2) Jika tindak pidana sebagaimana dimaksud dalam bab ini dilakukan oleh atau atas nama badan hukum, perseroan, perserikatan, yayasan atau organisasi lain, dan dilakukan orang-orang, baik berdasar hubungan kerja maupun berdasar hubungan lain, yang bertindak dalam lingkungan badan hukum, perseroan, perserikatan, yayasan atau organisasi lain, tuntutan pidana dilakukan dan sanksi pidana dijatuhkan terhadap mereka yang memberikan perintah atau yang bertindak sebagai pemimpin tanpa mengingat apakah orang-orang tersebut, baik berdasarkan hubungan kerja maupun berdasar hubungan lain, melakukan tindak pidana secara sendiri atau bersana-sama.

(3) Jika tuntutan dilakukan terhadap badan hukum, perseroan, perserikatan atau organisasi lain, panggilan untuk menghadap dan penyerahan suratsurat panggilan itu ditujukan kepada pengurus di tempat tinggal mereka, atau di tempat pengurus melakukan pekerjaan yang tetap.

(4) Jika tuntutan dilakukan terhadap badan hukum, perseroan, perserikatan, yayasan atau organisasi lain, yang pada waktu penuntutan diwakili oleh bukan pengurus, hakim dapat memerintahkan supaya pengurus menghadap sendiri di pengadilan.

Konsekwensi penerapan ketentuan tentang jawab korporasi ini harus benar-benar dipahami oleh para pengusaha, sehingga harus berhati-hati dalam mengelola perusahaannya agar tidak melakukan perbuatan yang mengakibatkan pengusaha dikenakan pidana penjara, di samping perusahaannya dikenakan denda, karena telah terjadi 
pencemaran danlatau perusakan lingkungan hidup yang diakibatkan oleh usaha dan/atau kegiatannya itu. ${ }^{41}$

\section{Masalah-Masalah yang Timbul dalam Pelaksanaan Ganti Rugi Tanah}

Permasalahan yang timbul dalam pelaksanaan ganti rugi tanah sangat bervariasi, namun yang menjadi masalah pokok yaitu dalam menentukan harga dan nilai tanah serta penggantian kehidupan yang layak.

Memasuki tahap penentuan harga tanah, bagi Panitia Pembebasan Tanah keberadaan dari tahap ini akan benar-benar diuji, sejauhmana pemihakan-pemihakan pada suatu kepentingan akan semakin mudah dibaca pada tahap ini. Cara penentuan harga tanah, dalam banyak kasus dalam prakteknya dilakukan setelah ada usulan untuk membebaskan dari si pemohon atau pengguna tanah.

Sebelum itu, hampir tidak diketahui dengan pasti seberapa besar nilai tanah di daerah tersebut, meskipun seandainya harga tanah di pasar tanah dapat dimonitor per daerah, serta belum mantapnya kerjasama secara sinergis misalnya antara PBB dengan BPN Departemen Pertanian, dan Depdagri membuat harga tanah secara real dan potensial belum dapat ditentukan dengan tepat. Ketidakmampuan itu salah satu sebab utamanya adalah nilai tanah yang sangat spekulatif dan subyektif yang mengandung unsur-unsur sosial psikologis yang sangat dalam dan sulit dihitung.

Dari penentuan harga tanah ini selanjutnya akan ditentukan seberapa besar ganti yang akan diberikan kepada tergusur. Melalui harga tanah ini bentuk dan sifat konflik pertanahan (kepentingan) yang akan timbul relatif mudah dipetakan, meskipun samar-samar. Harga tanah yang biasanya ditetapkan panitia pembebasan itu hanyalah nilai tanah dalam lingkup yang sempit, yaitu hanya harga fisik non ekonomis tanah saat itu, serta bendabenda fisik yang melekat diatasnya. ${ }^{42}$

Padahal nilai hak atas tanah jauh lebih luas dari nilai fisik-ekonomis karena yang dijadikan pertimbangan orang menguasai tanah adalah sangat banyak dan mungkin sulit dihitung. Karena ada aspek-aspek lain yang muncul dari penguasaan akan tanah yang dijadikan pertimbangan. Masalahnya adalah keberadaan aspek-aspek dimaksud sangat sulit dihitung

${ }^{41}$ Loc. Cit.

${ }^{42}$ Harga tanah ini menurut Keppres No.55 tahun 1993, Pasal 15 huruf a adalah didasarkan pada nilai nyata atau sebenarnya dengan memperhatikan. 
dan dinilai dengan sejumlah uang. Lalu bagaimana panitia pembebas menentukan harga hak atas tanah.

Memang secara formal sudah dijelaskan oleh beberapa peraturan mengenai bagaimana langkah-langkah yang harus dikerjakan. Seperti halnya yang tertuang dalam surat Depdagri Cq. Ditjen Agraria No.Ba.8/237/8/72, tanggal 8 Agustus 1972 mengenai pengumpulan data harga tanah secara berkala dengan mencatat harga tanah untuk berbagai jenis dan keperluan yang berlaku di masing-masing daerah. Harga tanah tersebut adalah harga pasaran, dalam arti harga yang benar-benar terjadi dalam jual-beli (rata-rata) selama triwulan sebelumnya. Kemudian juga secara berkala tiap akhir triwulan melaporkan hasil pencatatannya kepada BPN setempat.

Jika penentuan harga tanah memakai kriteria obyek pajak, ${ }^{43}$ maka pertama-tama yang harus dicermati adalah tata cara penentuan harga objek pajak yang kurang objektif sejalan dengan sifat dan nilai tanah yang subyektif dan spekulatif. Demikian juga pihak Dinas PBB yang masih belum mempunyai data akurat tentang harga tanah dan perkembanganya tiap tahun.

Bahkan seringkali penentuan NJOP itu untuk mudahnya dihitung secara pukul rata berdasarkan nilai suatu kawasan, daerah tertentu, sehingga seringkali sangat memberatkan pihak-pihak yang belum mampu mengoptimalkan nilai tanahnya.

Di sisi lain, terhadap tanah-tanah yang terancam digusur itu pajak yang dikenakan "kebetulan" sangat rendah, jauh di bawah manfaat real dan potensial yang diperoleh pemiliknya. Namun kecilnya penentuan pajak tersebut bukan karena nilai tanahnya yang rendah, namun karena ada faktorfaktor lain yang menentukannya seperti belum adanya sarana dan prasarana yang dibangun oleh pemerintah.

Dalam kondisi seperti ini tidak jarang muncul pihak ketiga yang ingin mengambil keuntungan, meskipun kadang-kadang hal itu terlalu dibesarbesarkan. Sehingga persoalannya pun menjadi bertambah rumit, apa lagi jika ada isu, dimana rakyat pada akhirnya menuduh pemerintah bertindak sewenang-wenang, diktator, korup, dan sebagainya. Bila persoalannya sudah demikian, maka hal ini dapat berkembang menjadi sebuah kerusuhan yang dapat mengancam stabilitas sosial. Upaya penanggulangannya akan bergeser menjadi masalah politik yang sangat peka, apalagi jika ada unsur kesengajaan di dalamnya.

${ }^{43}$ Keppres No.55 tahun 1993, Pasal 15 huruf a Jo. Keputusan Meneg Agraria/Ka/BPN No. 1/1994, Pasal 16 ayat (1) huruf a bahwa salah satu dasar yang menentukan besar kecilnya ganti rugi adalah Nilai Jual Objek Pajak (NJOP). 


\section{Penutup}

\section{A. Kesimpulan}

Berdasarkan uraian-uraian sebagaimana telah penulis kemukakan pada bab-bab sebelumnya tersebut di atas maka penulis dalam penulisan tesis ini menyimpulkan beberapa kesimpulan sebagai berikut:

1. Proses ganti rugi tanah dan pembebasan hak atas tanah yang terkena Lumpur Lapindo di Kabupaten Sidoarojo.

Proses ganti rugi tanah yang terkena lumpur PT. Lapindo Brantas yaitu tanggung jawab pemerintah dan PT. Lapindo Brantas, pemerintah dan PT. Lapindo Brantas harus berusaha agar dalam menentukan besarnya ganti rugi terdapat kata sepakat antara para anggota panitia dengan memperhatikan kehendak dari para pemegang hak atas tanah. Jika terdapat perbedaan taksiran masing-masing anggota. Keputusan tim panitia mengenai bentuk/besarnya ganti rugi tersebut disampaikan kepada pemerintah dan PT. Lapindo Brantas, para pemegang hak atas tanah dan para anggota panitia yang turut mengambil keputusan. Setelah menerima keputusan maka instansi dan para pemegang hak atas tanah yang bersangkutan memberitahukan kepada panitia pembebasan tanah tentang persetujuan atau penolakannya atas penentuan besar/bentuknya ganti rugi yang telạh ditetapkannya itu.

2. Pelaksanaan Ganti Rugi Tanah dan Bangunan yang terkena Lumpur Lapindo

Pelaksanaan pemberian ganti rugi dari PT LPI dilaksanakan oleh PT Marak Lapindo Jaya, salah satu perusahaan dalam group Bakrie. Pemberian ganti rugi tersebut akan dilaksanakan secara bertahap sesuai dengan ketentuan diatas. Perusahaan yang juga terkena dampak semburan lumpur, maka PT Minarak Lapindo Jaya (MLJ) akhirnya bersedia segera memberikan uang muka ganti rugi senilai $\mathrm{Rp} 42,7$ miliar kepada delapan perusahaan korban lumpur dari sebanyak 23 perusahaan yang menjadi korban Lumpur Lapindo itu. Pembayaran ganti rugi untuk pengusaha ini ada tiga tahap. Tahap pertarna adalah pembayaran uang muka sebesar 20 persen yang akan dibayarkan pada awal bulan Juni 2007 ini, kemudian tahap kedua 10 persen. Pembayaran tahap kedua ini khusus dibayarkan kepada perusahaan yang masih mempunyai hutang di luar, sehingga bukan pengusaha yang 
menerima tetapi pihak pengutangnya yang menerima. Pembayaran tahap kedua ini akan dibayar pada awal bulan Juli tahun ini juga. Kemudian pembayaran tahap ketiga sebesar 70 persen, dan akan dibayarkan antara bulan Mei sampai Desember tahun 2008.

3. Penyelesaian Ganti Rugi Tanah yang tekena Lumupur Lapindo Berantas

Menurut hasil tim kajian semburan Lumpur panas di Sidoardjo yang dibentuk Komnas HAM, Lumpur panas telah membuat warga Porong dan sekitarnya tercabut haknya. Di antaranya hak atas lingkungan yang sehat, hak atas pekerjaan dan hak untuk memperoleh informasi. Gugatan dan tuntutan diajukan kepada PT Lapindo Brantas untuk bertanggung jawab terhadap dampak yang ditimbulkan akibat pengeboran y ang dilakukan. Seberapa $3 a u b$ perseroan barns bertanggung jawab atas kesalahan yang dilakukan, landasannya tercantum dalam UU No. 1 Tahun 1995 yang kemudian diubah menjadi Undang-Undang No 40 Tahun 2007 , seperti yang telah diuraikan sebelumnya. Menurut undangundang tersebut dinyatakan bahwa tanggung jawab perseroan dilaksanakan oleh direksi, besarnya ganti rugi oleh perusahaan sebatas kekayaan perusahaan tersebut, kecuali apabila dapat dibuktikan adanya unsur pelanggaran dan kelalaian dalam melaksanakan tugasnya, maka tanggung jawab akan sampai pada harta pribadinya. Tanggung jawab pemegang saham sesuai pengaturan dalam pasal 3 hanya bertanggung jawab terbatas sampai dengan besarnya saham yang dimilikinya. Namun dengan adanya doktrin piercing the corporate veil, apabila yang kelalaian yang dilakukan diketahui oleh pemegang saham, maka prinsip tanggung jawab terbatas menjadi tanggung jawab tidak terbatas.

\section{B. Saran}

Berdasarkan kesimpulan sebagaimana penulis kemukkan tersebut di atas maka penulis memberikansaran sebagai masukan kepada semua pihak yang bertanggung jawab atas bencana yang disebabkan oleh PT. Lapindo Berantas adapun saran tersebut sebagai beikut:

1. Diharapkan upaya pemerintah dalam mengatasi perbedaan pendapat tentang standar ganti rugi dengan membentuk tim apprasial (penaksir) harga dalam penetapan ganti rugi, yang keberadaanya tim ini didatangkan kalau sudah terjadi permasalahan dalam penetapan standar uang ganti rugi antara pantia pengadaan tanah dengan para pemilik tanah. Kondisi yang 
demikian bisa menciptakan kondisional yang tidak kondusif dan sekaligus mengurangi kepercayaan masyarakat terhadap eksistensi pemerintah.. Idealnya keberadaan tim appraisal itu harus sudah ada sejak awal proses pengadaan tanah, agar bisa mengakomodir segala permasalahan yang berkaitan dengan penetapan besarnya ganti rugi.

2. Upaya pemerintah dalam mengatasi ganti rugi tanah yang terkena lumpur lapindo sudah membentuk tim nasional penanggulangan semburan lumpur di sidoarjo juga melakukan trobosan kecil dengan peningkatan pemberian uang ganti rugi ini dinaikan berkisar antara 10-15\% dari NJOP, sebaiknya pemerintah dalam memberikan kenaikan uang ganti rugi ini harus sampai pada tingkat kelayakan atau paling sedikit sama dengan harga.pasaran yang berlaku di suatu tempat.

3. Kewenangan yang ada pada pemerintah dalam penguasaan, pengaturan terhadap tanah harus ditegakkan, demi untuk memberikan kepastian hukum dalam ganti rugi tanah dan bangunan khususnya tanah dan bangunan yang terkena lumpur lapindo brants di Kabupaten Sidoarjo. Seiring dengan kemajuan informasi teknologi, maka Sistem Infromasi pertanahan (SIP) harus segera diciptakan dan disempurnakan agar pengelolaan dan prosedur pertanahan bisa mengikuti perkembangan jaman. 


\section{Daftar Pustaka}

Abdulrahman. Masalah Pencabutan Hak-hak atas tanah, Pembebasan Tanah dan Pengadaan Bagi Pelaksanaan Pembangunan untuk Kepentingan Umum, Bandung: Citra Aditya Bakti, 1996.

Ali, Zainuddin. Sosiologi Hukum, Palu: Yayasan Masyarakat Indonesia Baru, 2004.

Bailey, Kenneth D. Methods of Social Research, The Pree Press, A Division of Macmillian Publishing Co., Inc. New York, London.

Efendi ,Sofyan. Hukum Agraria di Indonesia, Kumupulan Lengkap UndangUndang dan Peraturan-Peraturan jilid 4, Jakarta: Ghalia Indonesia, 1984.

Hermit, Herman. Cora Memperoleh Sertifikat Tanah Hak Milik, Tanah Negara, dan Tanah PEMDA: Teori dan Praktik Pendaftaran Tanah di Indonesia. Cet. I. Bandung: Mandar Maju, 2004.

Harsono, Budi. Hukum Agraria Indonesia, Sejarah Pembentukan UUPA, Isi dan Pelaksanaannya, Jilid I Jakarta: Djambatan, 1999.

---Hukum Agraria Indonesia, Sejarah Penyusunan Isi dan Pelaksanaannya Jilid I Hukum Tanah Nasional, Jakarta: Djambatan, Edisi Revisi 2003.

Hasni. Modul Hukum Penatagunaan Tanah/Ruang, Jakarta: Fakultas Hukum Universitas Trisakti, 2003.

Hutagalung, Arie S. dkk. Asas-asas Hukum Agraria: Bahan Bacaan Pelengkap Bahan Perkuliahan Hukum Agraria. Depok: FH-UI, 2001.

------ Serba Aneka Masalah Tanah dalam Kegiatan Ekonomi (Suatu Kumpulan Karangan), Jakarta: Penerbit FH-UI, 2002.

Mulyadi. Pengadaan Tanah untuk Kegiatan Pembangunan di Perkotaan, Pusat Penelitian dan Pengembangan BPN, Jakarta: 1998.

Mulyadi, Kartini. dan Wijaya, Gunawan, Hak Hak Atas Tanah, Jakarta: Prenada Media, 2004.

Prodhisita, Chai. Theoritical Terminological and Philosophical Issue A Qualitative Research, dalam Atting et. Qualitative Research Methods.

Parlindungan, A. Pedoman Pelaksanaan UUPA dan Tata Cora Pejabat Pembuat Akta Tanah. Cet. III. Bandung: Alumni, 1978. 
Pencabutan dan Pembebasan Atas Tanah: Suatu Studi Perbandingan.Cet. III. Bandung: Mandar Maju, 1993.

Peranginangin, Effendi. Hukum Agraria I: Dasar dan Sistematika Hukum Agraria, Tinjauan UUPA pasal demi Pasal, Macam Hak Atas Tanah, Sifat dan Isinya (Seri I). Jakarta: Notariat FH UI, 1979.

.Hukum Agraria I; Dasar dan Sistematika Hukum Agraria, Tinjauan UUPA pasal demi Pasal,Macam Hak Atas Tanah, Sifat dan Isinya (Seri II). Jakarta: Notariat FHUI, 1979.

Rosalijo, Mariam M. Tinjauan Pencabutan Hak Atas Tanah dan Benda Benda Yang Ada diAtasnya Jakarta: Ghalia Indoesia,1979.

Soebekti, R dan R. Tjirosudibio. Kitab Undang-undang Hukum Perdata. Jakarta: Pradnya Paramita, 2001.

Soeprapto, R. Undang-undang Pokok Agraria Dalam Praktek. Jakarta: Mitra Sari, 1986.

Saleh, K. Wantjik. Hak Anda Atas Tanah, Jakarta: Ghalia Indonesia, 1992.

Susanto, R. Hukum Pertanahan (Agraria), Jakarta: Pradnya Paramita, 1983

Silalahi. Pengadaan Tanah Bagi Pembangunan Daerah dan Penetapan Harga Tanah, Pertanahan dan Pemetaan Propinsi DKI Jakarta, Naskah disampaikan pada seminar pertanahan, Puncak 17 Desember 2004.

Santoso, Bambang. Haris, Abdul, Prasetyo, Iris., Paradigma Baru Pengelolaan Pertanahan Pada Era Otonomi Daerah, Bapenas, Jakarta, 2000.

Silabus Mata Kuliah Pengadaan Tanah: Hasil Raker PSHA Semester Genap, 2003-2004.

Sihombing, Irene Eka. Silabus Mata Kuliah Pengadaan Tanah, Fakultas Hukum Universitas Trisakti, Jakarta 2005 - 2006.

-------, Transparansi Bahan Kuliah Pengadaan Tanah, Fakultas Hukum Universitas Trisakti, Jakarta, 2005.

Sunarya, Basuki. Garis Besar Hukum Tanah Indonesia Landasan Hukum Penguasaan dan Penggunaan Tanah, Fakultas Hukum Universitas Trisakti, Jakarta.

Soekanto, Soerjono, dan Sri Mahmudji. Penelitian Hukum Normatif, Jakarta: Raja Grafindo Peersada, 2004. 


\section{Sumber Internet}

Sodiki, Achmad, "Pembaruan Hukum Pertanahan Nasional Dalam Rangka Penguatan Agenda Landreform", artikel pertanahan dari internet $<$ http://www.google.com>, diakses tanggal 23 Oktober 2005.

Talkurputra, Nad Darga. Proses Otomatisasi^Perencanaan Spasial Untuk Penggunaan Tanah, <http://www.google.com> diakses tanggal 2 Oktober, 2005.

"LSM Khawatir Pernyataan Bagir tentang Lapindo Pengaruhi Penegakan Hukum. "<http://www.hukumonline.com/detail.asp?id=15298\& $\mathrm{cl}^{\wedge}$ BBeri ta> diakses tanggal 10 Juli 2006.

"Pemerintah, BP Migas dan Lapindo Brantas dianggap lakukan kejahatan lingkungan",

$<$ http://www.beritabumi.or.id/berita3.php?idberita $=56319>$, diakses tanggal 19September 2006.

"PKB Urus Sertifikat Tanah Korban Lumpur Lapindo." <http://www. Indonesia.co.id/index.php/contentlview/1749/827/>, diakses tanggal 12 Oktober 2006.

"Lapindo Kesulitan Uang", <http://www.indomedia.com/bpost/1120s06/10/ depan/utamal1,htm>, diakses tanggal 19 Juni 2006.

"Analisis Geolog Eropa di Koran Inggris." < http://www.jawapos.co.id/ index.php? act=detail\&id=7492>, diakses tanggal 23 September 2006

\section{Peraturan Perundang-undangan}

Indonesia, Undang-undang Tentang Pokok-Pokok Agaria (UUPA), UU No. 5 Tahun 1960, LN No. 104 Tahun 1960, TLN No. 2043.

Indonesia, Undang-undang tentang Ketentuan-ketentuan Pokok Transmigrasi. UUNo.3 tahun 1972.

Indonesia, Peraturan Pemerintah Rl tentang Penyelenggaraan transmigrasi. Direktorat Jendral Transmigrasi dan Direktorat pelaksanaan pemindahan transmigran, PP No. 42 Tahun 1973.

Indonesia, Peraturan Pemerintah Tentang Penunjukkan Badan-badan Hukum Yang Dapat Memiliki Hak MilikAtas Tanah, PP No. 38 Tahun 1963, LN No. 61 Tahun 1963. 
Indonesia, UUNo.29 tahun 1956 Tentang Peraturan peraturan dan Tindakantindakan Mengenai Tanah Perkebunan.

Indonesia, Peraturan Presiden Tentang Perubahan Atas Peraturan Presiden Tentang Pengadaan Tanah Bagi Pelaksanaan Pembangunah Untuk Kepentingan Umum, Perpres No. 65 tahun 2006.

Peraturan Presiden No.36 tahun 2005 tentang Pengadaan Tanah Bagi Pelaksanaan Pembangunan untuk Kepentingan Umum, Jakarta: 2005.

Keputusan Presiden No.55 tahun 1993 tentang Pengadaan Tanah Bagi Pelaksanaan Pembangunan untuk Kepentingan Umum, Jakarta: 1993 